\title{
The Basset Horns of Franz Doleisch in Czech and
} Worldwide Instrument Collections

\section{Róbert Šebesta - Daniela Kotašová}

Abstract: A biography of Franz Doleisch, a Prague maker of woodwind instruments, summarises the facts so far known about his life. Basset horns account for more than half of the instruments he made. Preserved specimens from $\mathrm{Czech}$ and foreign collections are described with respect to their characteristic morphological features, bore diameter, the number and design of the keys, and the trademark. Although the evaluation of findings with respect to the quality of workmanship shows that he was one of the leading Czech instrument makers of his day, current musical organology literature has not yet reflected this fact. The goal of the present study is to present the first phase of research on instruments made by Doleisch, with the intention of drawing attention to one of the elite European instrument makers of the latter half of the $18^{\text {th }}$ century.

Key words: Franz Doleisch, basset horn, Czech Museum of Music instrument collection, woodwind instruments, clarinet, aerophones, wind instrument making, Franz Strobach, Theodor Lotz

Today, the basset horn is a relatively little-known instrument despite its significant and artistic use in masterpieces by Wolfgang Amadeus Mozart. ${ }^{1}$ This single-reed instrument of the clarinet family is usually tuned in F, and its alto-tenor range is suitable for the ambitus of middle voices. ${ }^{2}$ According to Franz Xaver Glöggl (1764-1839), an Austrian musician who apparently played the basset horn in addition to conducting and writing about music,

This work was financially supported by the Ministry of Culture of the Czech Republic

(DKRVO 2019-2023/21.I.a, National Museum, 00023272).

1) We wish to thank the entire team that contributed to the creation of this article through their advice, comments, or valuable assistance with obtaining supporting materials for our study. Those persons are Albert R. Rice, Gabrielle Rossi-Rognoni (Royal College of Music Museum, London, hereinafter RCM), Richard Martin (RCM), Géry Dumoulin (Musée des Instruments de Musique, Brussels, hereinafter MIM), D. Check Reeves (National Music Museum in Vermillion - University of South Dakota, hereinafter NMM Vermillion), Mingzhe Wang (Michigan State University College of Music, originally a private collection of Charles Aurand in Tucson, Arizona (hereinafter Aurand CM Michigan), Jakub Kydlíček and Michaela Hejlová (Prague Conservatoire, hereinafter PK), Kateřina Krylová and Magdaléna Šustová (The City of Prague Museum, hereinafter MMP), and our colleagues from the National Museum - Czech Museum of Music in Prague (hereinafter NM-ČMH). 2)Fordetails, seeSHACKLETON, Nicolas:Basset-horn[entry]. Retrievedfrom: https://www.oxfordmusiconline. com/grovemusic [accessed on 14 Apr. 2021]. 
"Bassetthorn (corno Bassetto) ist ein sehr angenehmes Blasinstrument von Holz; welches ums J. 1760 von einem Deutschen erfunden, und im J. 1782 zu mehrerer Vollkommenheit durch Theodor Lotz gebracht wurde". Because the instrument subsequently spread to central Europe, its further development had a major influence on instrument makers working in the territory of what is now the Czech Republic and Slovakia. The structural innovations of Theodor Lotz (1746-1792), Franz Doleisch the Elder (1748/49-1805), and Franz Strobach (ca. 1769-1812) left an indelible mark on the history of the basset horn and are of key importance to its development. While the basset horns of Theodor Lotz and Franz Strobach have already been subjected to detailed organological research in recent years, ${ }^{4}$ the instruments produced by the Prague woodwind instrument maker Franz Doleisch the Elder still await comprehensive evaluation.

The earliest mention of Doleisch that we find in the extant historical literature is in the seventh volume of a history encyclopaedia by Joseph Anton von Riegger, in which Gottfried Johann Dlabacž already gives a brief, informative evaluation in 1788: "Dolegschy, ein berühmter Kunstdrechsler, macht die beßten Hoboes, Flauten, Klarinette und Fagots. " ${ }^{\prime}$ He is characterised as a famous instrument maker and as the best maker of woodwind instruments, and this is fully supported by the quality of his preserved instruments. The absence of any mention of the basset horn may indicate that Doleisch had not yet begun making them at the time. Ernst Ludwig Gerber's study (1812) repeats the information published by Dlabacž in 1788 almost verbatim. ${ }^{6}$ The next evaluation of instruments made by Doleisch dates from the latter half of the $20^{\text {th }}$ century. In the 1970 s Jindrich Keller, curator of the musical instrument collection at the National Museum in Prague, became the first author of the modern era to devote himself

3) GLÖGGL, Franz Xaver: Allgemeines musikalisches Lexikon, in vier Abtheilungen: Aus den bewährtesten Schriftstellern, Selbstverlag, Linz 1812, 1. Abtheilung, p. 46.

That the basset horn was invented in Germany in ca. 1760 is made more probable by the fact that F. X. Glöggl's father, Joseph Glöggl, was known as one of the first basset horn teachers. A. Rice drew attention to this fact in 2009. Cf. RICE, Albert R.: From the Clarinet D’Amour to Contra Bass: A History of Large Size Clarinets, 1740-1860, Oxford University Press, New York 2009, p. 101 (hereinafter RICE 2009).

4) Cf. ŠEBESTA, Róbert - HOEPRICH, Eric: Franz Strobach: basset horns and new biographical information, in: Journal of the American Musical Instrument Society (JAMIS), vol. 36, 2010, pp. 58-77; ŠEBESTA, Róbert: Produkcia Strobachových basetových rohov vo svetle nových biografických poznatkov (Strobach's Production of Basset Horn in Light of New Biographical Discoveries), Opus musicum, vol. 41, 2009, no. 3, pp. 17-24 (hereinafter ŠEBESTA 2009); ŠEBESTA, Róbert: Nástrojár Johann Theodor Lotz vo svetle historickej dokumentácie: najnovšie objavy a zhodnotenie (The Instrument Maker Johann Theodor Lotz in Light of Historical Documentation: The Latest Discoveries and Evaluations), Clavibus unitis, vol. 5, 2016, pp. 1-14. Retrieved from https://www.acecs.cz/media/cu_2016_05_sebesta.pdf [accessed on 13 May 2021]; PIDDOCKE, Melanie Anne: Theodor Lotz: a biographical and organological study. Edinburgh Research Archive, The University of Edinburgh 2012 (hereinafter PIDDOCKE 2012). Retrieved from https://era.ed.ac.uk/handle/1842/7707 [accessed on 19 March 2021].

5) DLABACŽ, Johann Gottfried: Versuch eines Verzeichnisses der vorzüglichern Tonkünstler in oder aus Böhmen, in: Materialien zur alten und neuen Statistik von Böhmen, ed. Joseph Anton von Riegger, Heft VII, Kaspar Widtmann, Prag - Leipzig 1788, p. 162.

6) GERBER, Ernst Ludwig: Neues historisch-biographisches Lexikon der Tonkünstler, A. Kühmel, Leipzig 1812, vol. 1, col. 911. Dlabač's lexicon (1815) gives almost the exact same information; cf. DLABACŽ, Johann Gottfried: Allgemeines historisches Künstler-Lexikon für Böhmen und zum Theil auch für Mähren und Schlesien, Prag 1815, vol. 1, col. 333. 
to this topic in more detail. ${ }^{7}$ His research is the source of all biographical information so far known about Franz Doleisch the Elder and his son Franz Doleisch the Younger. He drew the information primarily from public records published in a study by Antonín Podlaha in 1917. ${ }^{8}$ From among Doleisch's preserved instruments, he mentions two oboes, two clarinets, and three basset horns, which he rated as the best of the instruments from Czech makers. Following up on his research in individual texts was Bohuslav Čížek, who added three specimens from the collection of the Prague Conservatoire to Keller's list of Doleisch's preserved basset horns. ${ }^{9}$ The important Scottish organologist Lyndsay G. Langwill already presented basic biographical and organological information from a foreign encyclopaedic database in 1972, ${ }^{10}$ and William Waterhouse followed up on his work in $1993 .{ }^{11}$ At the same time, Phillip T. Young, an American organologist specialising in woodwind instruments, published the results of his research, in which he updated the list of preserved basset horns made by Franz Doleisch and gave the details of records of their trademarks, the number of keys, and the bore diameter. ${ }^{12}$ In connection with Mozart's activities in Prague, Colin Lawson gives a list of Doleisch's preserved basset horns, compiled by Nicholas Shackleton, in a study dated 1996. ${ }^{13}$ A decade later, Thomas Grass and Dietrich Demus followed up on his work, evaluating the progressiveness of Doleisch's basset horns, especially from the perspective of the use of a diatonic and a chromatic basset register. ${ }^{14}$ Eric Hoeprich describes Doleisch's pivotal standing in the making and popularity of basset horns in Bohemia in his 2008 monograph. ${ }^{15}$ Besides already known biographical information about Doleisch the Elder and the Younger, the more comprehensive research of the American organologist Albert R. Rice

7) KELLER, Jindřich: Pištělníci a trubaři. Pojednání o výrobě dechových hudebních nástrojů v Čechách před rokem 1800 (Makers of Pipes and Trumpets. A Discussion of the Making of Wind Instruments in Bohemia before 1800), in: Sborník Národního muzea v Praze. Series A, vol. 29, 1977, nos. 4-5, pp. 180, 199, 201, 204, 206, 210, 212-213, 226-227 (hereinafter KELLER 1977).

8) PODLAHA, Antonín: Materiálie k slovníku umělců a uměleckých řemeslníků $v$ Čechách (Materials for a Dictionary of Artists and Artisans in Bohemia), in: Památky archeologické (Archaeological Artefacts), vol. 29, 1917, p. 272. 9) ČÍŽEK, Bohuslav: Nástrojové sbirky pražské konzervatoře (Instrument Collections of the Prague Conservatoire), Hudební nástroje (Musical Instruments), vol. 18, 1981, no. 2, p. 58 (hereinafter ČížEK 1981); ČÍŽEK, Bohuslav: Nástrojové sbírky pražské konzervatoře (Instrument Collections of the Prague Conservatoire), thesis, Univerzita Karlova, Praha 1983, Part 2 (catalogue), pp. 48-53.

10) LANGWILL, G. Lyndesay: An Index of Musical Wind-Instrument Makers, $3^{\text {rd }}$ ed., Lyndesay G. Langwill, Edinburgh 1972, p. 37 (hereinafter LANGWILL 1972); LANGWILL, G. Lyndesay: An Index of Musical WindInstrument Makers, $6^{\text {th }}$ ed., Lyndesay G. Langwill, Edinburgh 1980, p. 41 (hereinafter LANGWILL 1980).

11) WATERHOUSE, William: The New Langwill Index: $\mathcal{A}$ Dictionary of Musical Wind-Instrument Makers and Inventor, Tony Bingham, London 1993 (first edition), p. 92.

12) YOUNG, Phillip T.: 4900 Historical Woodwind Instruments: An Inventory of 200 Makers in International Collections, Tony Bingham, London 1993, pp. 65-66 (hereinafter YOUNG 1993).

13) LAWSON, Colin: Mozart Clarinet Concerto, Cambridge University Press, Cambridge 1996, p. 84, 87 (hereinafter LAWSON 1996).

14) The diatonic basset register has the notes $d$ and $c$, while the chromatic register has e flat, $d, c$ sharp, and $c$. GRASS, Thomas - DEMUS, Dietrich: Das Bassetthorn. Seine Entwicklung und seine Musik, Books on Demand $\mathrm{GmbH}$, Norderstedt 2004 ( $2^{\text {nd }}$ edition), p. 255 (hereinafter GRASS-DEMUS 2004).

15) HOEPRICH, Eric: The Clarinet. The Yale Musical Instrument Series, Yale University Press, New Haven and London, 2008, p. 241 (hereinafter HOEPRICH 2008). 
from 2009 provides detailed specifications for the construction and design of his basset horns such as, e.g. decorated levers for the a flat $/ e$ flat ${ }^{2}$ and $f / c^{2}$ keys, connecting the knee to the right-hand joint as an integral piece or needle-like pins for the keys. ${ }^{16}$ The effectiveness of the chosen designs for Doleisch's basset horns in the context of the period production of instrument makers is also dealt with on a comparative basis in one of the areas of discussion of a doctoral dissertation by the Australian scholar Melanie Piddocke (2012). ${ }^{17}$

After the passing of more than 200 years, on the basis of the current results of research, we can concur with Dlabacžs assertion that Franz Doleisch (also spelled variously as Dolejš, Doleysch, Doleyssý, Dolegschy, or Dolegssy) was one of the most important Czech instrument makers of the latter half of the $18^{\text {th }}$ century. He dated his products and marked them with the Bohemian lion, his name, and a star (from 1799 a double-headed eagle). The earliest preserved instrument from 1781 marks the beginning of his activity as an instrument maker. ${ }^{18}$ He worked in Prague all his life. From 1792 to 1796 the Prague instrument maker Josef Hallas (1779-1844) did an apprenticeship with him. ${ }^{19}$ The famed Carlsbad instrument maker Franz Strobach (1769-1812) was apparently another of his apprentices. At the end of his life he resided in the Old Town in house no. 692. He died on 9 June 1805 at the age of $56 .{ }^{20} \mathrm{After}$ his death, the workshop was taken over by his son Franz Doleisch the Younger (1774-1810), who shared the same company trademark and continued the practice of dating instruments. Keller states that from 1807 to 1810 Doleisch the Younger was the leader of Prague's guild for makers of violins and wind instruments. We also know from the same source that in 1811-1812, after the death of Doleisch the Younger, Anna Doleischová, the widow of Doleisch the Elder, ran the company. ${ }^{21}$

\section{Preserved basset horns}

Doleisch's oboes, clarinets, basset horns, and bassoons exhibit high-quality craftsmanship and functionality (playing properties). This is shown by more than 20 preserved instruments in European and American instrument collections. More than half of them are basset horns. In proportion to the three oboes, four clarinets, and two bassoons, the fourteen preserved basset horns represent a sampling of instruments from which structural and design standards

16) RICE 2009, op. cit. in footnote no. 3, pp. 157-158.

17) PIDDOCKE 2012, op. cit. in footnote no. 4, pp. 177-178. In the 2015 Czech-language doctoral dissertation of the clarinettist and bass clarinettist Lukáš Daňhel, a Franz Doleisch basset horn is also briefly mentioned. DAŇHEL, Lukáš: Basetový roh - historický vývoj a dnešni použití (The Basset Horn - Its Historical Development and Present-Day Use), selected doctoral dissertations, Janáček Academy of Performing Arts in Brno, Ediční středisko JAMU, Brno 2015, p. 33.

18) The instrument in question is a 4-keyed oboe from 1781, kept in the collection of the NM-ČMH under inv. no. E 324.

19) KURFÜRST, Pavel: Brněnští hudební nástrojaři 14.-19. století (Brünner Instrumentenbauer des 14.19. Jahrhunderts), Moravské muzeum, Brno 1980, p. 67.

20) KELLER 1977, op. cit. in footnote no. 7, p. 213. Based on this information, we estimate that he was born in 1749.

21) Ibid. 
can be determined. On the basis of their dating (1790-1803), we assume that they were all made by Franz Doleisch the Elder.

\section{Overview of preserved basset horns made by Franz Doleisch}

(the list below gives descriptions of individual instruments and all available information about structure and dimensions)

\begin{tabular}{|c|c|c|c|c|c|c|}
\hline & $\begin{array}{l}\text { Year } \\
\text { made }\end{array}$ & Tuning & Location, collection, inv. no. & Keys & $\begin{array}{c}\text { Bore } \\
\text { diameter }\end{array}$ & Trademark \\
\hline 1 & 1790 & In $\mathrm{F}$ & Prague: NM-ČMHE 3008 & $8(c)$ & 13.6 & $\begin{array}{l}\text { Bohemian lion / DOLEISCH / } \\
\text { PRAG / } 1790 \text { / ** }\end{array}$ \\
\hline 2 & 1791 & In $\mathrm{F}$ & Prague: NM-ČMHE 467 & $8(d, c)$ & $13.8-14.4$ & $\begin{array}{l}\text { Bohemian lion / DOLEISCH } \\
\text { PRAG / 1791 / * }\end{array}$ \\
\hline 3 & ca. 1792 & In $\mathrm{F}$ & Prague: NM-ČMHE 476 & $8(d, c)$ & 13.8 & no stamp - attributed \\
\hline 4 & ca. 1793 & $\operatorname{In} \mathrm{F}$ & Halle: Händel-Haus MS-406 & $7(c)$ & 13.8 & no stamp - attributed \\
\hline 5 & 1793 & In $\mathrm{F}$ & $\begin{array}{l}\text { Prague: NM-ČMH E } 464 \\
\text { written off from the collection }\end{array}$ & $8(d, c)$ & & $\begin{array}{l}\text { Bohemian lion / DOLEISCH / } \\
\text { PRAG / 1793 / * }\end{array}$ \\
\hline 6 & 1793 & In $\mathrm{F}$ & USA, NMM Vermillion 3541 & $8(d, c)$ & 13.0 & $\begin{array}{l}\text { Bohemian lion / DOLEISCH / } \\
\text { PRAG / 1793 / * }\end{array}$ \\
\hline 7 & 1796 & In $\mathrm{F}$ & Prague: NM-ČMHE 466 & $9($ eflat, $d, c)$ & $13.2-13.3$ & $\begin{array}{l}\text { Bohemian lion / DOLEISCH / } \\
\text { PRAG / } 1796 \text { / * }\end{array}$ \\
\hline 8 & 1797 & In $\mathrm{F}$ & Brussels: MIM 938 & $9($ eflat $, d, c)$ & 13.8 & $\begin{array}{l}\text { Bohemian lion / DOLEISCH } / \\
\text { PRAG / 1797/***/3 } \\
\end{array}$ \\
\hline 9 & 1798 & In $\mathrm{F}$ & Prague: PK M I/43 & $10(c)$ & $13.1-13.8$ & $\begin{array}{l}\text { Bohemian lion / DOLEISCH } \\
\text { PRAG / } 1798 \text { /** }\end{array}$ \\
\hline 10 & 1798 & In $\mathrm{F}$ & Prague: PK M I/44 & $6(c)$ & 13.7 & $\begin{array}{l}\text { Bohemian lion / DOLEISCH } / \\
\text { PRAG / 1798 /* }\end{array}$ \\
\hline 11 & 1798 & In $\mathrm{F}$ & Prague: PK M I/42 & 12 (eflat, $d, c$ ) & $13.8-14.4$ & $\begin{array}{l}\text { Bohemian lion/ DOLEISCH / } \\
\text { PRAG / } 1798 \text { /*** }\end{array}$ \\
\hline 12 & 1800 & In $\mathrm{F}$ & USA: Aurand-CM Michigan & $13(d, c)$ & & $\begin{array}{l}\text { Double-headed eagle / } \\
\text { DOLEISCH / PRAG / } 1800 \\
\text { /*** }\end{array}$ \\
\hline 13 & 1803 & In $\mathrm{F}$ & London: RCM 90 & $9($ eflat $, d, c)$ & 13.2 & $\begin{array}{l}\text { Double-headed eagle / } \\
\text { DOLEISCH / PRAG / 1803 / } \\
\star * \star / F\end{array}$ \\
\hline 14 & 1803 & In $\mathrm{F}$ & Prague: MMP H 189 529/001 & $6(d, c)$ & & $\begin{array}{l}\text { Double-headed eagle / } \\
\text { DOLEISCH / PRAG / 1803/ } \\
\star * / F\end{array}$ \\
\hline
\end{tabular}

\section{Morphology and design}

Franz Doleisch made what is called an angular type of basset horn with a multi-angled body. Its characteristic feature was a barrel (the separate part below the mouthpiece) slightly bent at an angle of ca. $155^{\circ}$. However, the earliest dated basset horn with an original straight barrel from 1790 (NM-ČMH, inv. no. E 3008) indicates that Doleisch did not begin angling the barrel until $1791 .{ }^{22}$ He seems to have borrowed this morphological element from basset horns

22) The basset horn from 1803 (RCM, inv. no. 90) also has a straight barrel, but it is not the original barrel. 
of the Dresden instrument makers August Grenser (1720-1807) and Jakob Grundmann (1727-1800). ${ }^{23}$ The influences of these older and more experienced colleagues, who were among Germany's elite instrument makers and were working in nearby Dresden, can also be seen in the imitation of their practice of dating instruments and in the conception of the narrower "clarinet-style" bore.

The second joint of Doleisch's basset horn is found in the middle of the body at an angle of ca. $117^{\circ}$. That angle is made by the "knee", which is joined to the right-hand joint as an integral section. The joining of the knee with the right-hand joint differs from the design used by most of Doleisch's colleagues, who made the knee as a separate part to simplify the manufacturing process. The advantage of joining the two parts as an integral joint was making the instrument more compact without limiting the position of the basset horn when played to the right of the player's body or in a central position between the player's legs. In connection with this, the renowned German clarinettist Johann Heinrich Backofen said in 1803 that clarinettists who play with the reed against the lower lip played the basset horn with the instrument placed to the right (of the player's body), while a central position was used by players with the reed against the upper lip. ${ }^{24}$

Doleisch's basset horns are angled most acutely at the "book", a wooden box that contains tubing that meanders through turns at a $180^{\circ}$ angle before opening into the brass bell. ${ }^{25}$ This feature differentiated the basset horn from the oboe da caccia (with which it shares an original curved shape) from the very beginning of its existence. The winding tubing in the book provided a sufficient extension of the lower "basset" register without increasing the external length of the instrument, thereby securing an acoustically advantageous position of the bell above the floor to help the sound spread into space efficiently when the player is seated. ${ }^{26}$ While Viennese basset horns placed the three channels side by side (the book is flat), Doleisch arranged them into a triangle as German instrument makers did. The second

23) The earliest basset horn made by Carl Augustinus Grenser the Younger dates from 1784 and is kept in the collection of the Scenkonstmuseet in Stockholm, inv. no. M553 (retrieved from https://mimo-international. com/MIMO/doc/IFD/OAI_SMS_MM_POST_553) [accessed on 8 Apr. 2021]. The oldest basset horn made by Jakob Grundmann, also from 1784 belongs to Rudolf Tutz the Elder in Innsbruck. See SCHLADER, Ernst - TUTZ, Rudolf: Das früheste bekannte Bassethorn von Jakob Friedrich Grundmann, in: Geschichte, Bauweise und Repertoire der Klarinetteninstrumente. Michaelsteiner Konferenzberichte, Band 77, eds. Monika Lustig - Boje E. Hans Schmuhl, Kloster Michaelstein - Musikakademie/Museum, Augsburg - Michaelstein 2008, pp. 123-126.

24) BACKOFEN, Johann Heinrich: Anweisung zur Klarinette (Neue teoretisch-prachtische Klarinett Schule) nebst einer kurzen Abhandlung über das Bassett-Horn, Leipzig 1803, reprint: Moeck Verlag, Celle 1986, p. 37 (hereinafter BACKOFEN 1803).

25) The "book" (sometimes called the "box") is the word for the case or box that contains three interconnected channels of tubing. The double bend of the channels shortens the external length of the basset horn so that when played sitting down, the bell remains in the proper acoustical position above the floor while maintaining the necessary length of tubing for the lowest notes of the basset horn. The shape of the "box" with three successively arranged channels resembles a book, so the word "book" has caught on as the contemporary technical term in the English language. In the German language, the historical term "Kasten" ("box") is used. 26) The word "basset", a diminutive form of the word "bass", is used in the phrase "basset register" to designate the instrument's lowest range, while in the name of an instrument, the word "basset" indicates the ability to play in the bass register, but not as low as a bassoon, contrabass, etc. 


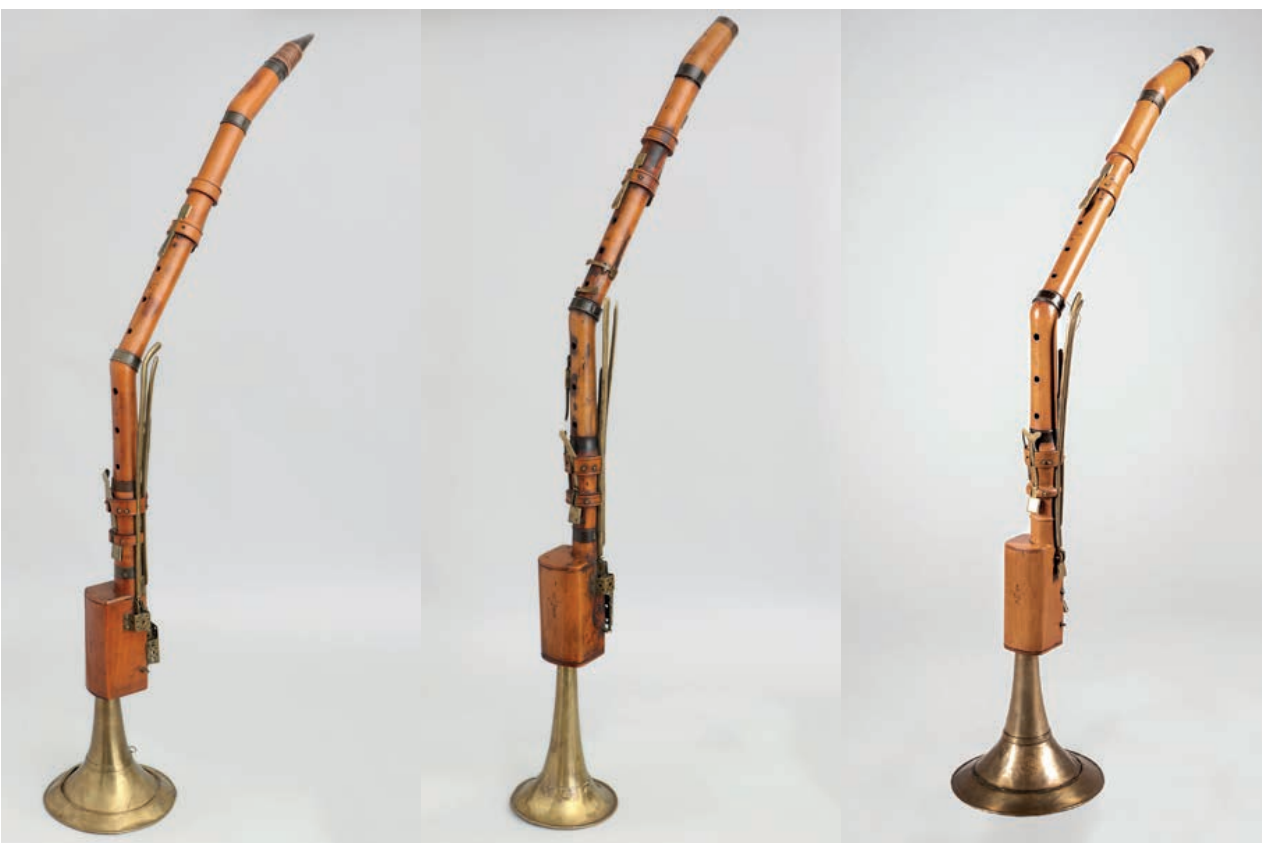

\section{Basset horns: series of instruments}

NM-ČMH E 466, PK M I/ 42, NM-ČMH E 467 (left to right)

(๑) Jan Kř́ženecký

channel is on the right, and the third channel protrudes forward from the corpus, giving the wooden case of the book more of a box-like shape. Keys for the basset register are placed on the smooth back of the book, and they are operated by the thumb of the right hand.

A peculiar design feature of Doleisch's basset horns (and clarinets) is the decorating of the edges of the wooden rings. ${ }^{27}$ From the sampling of 14 basset horns, we can see that Doleisch began decorating the rings in ca. 1793. The instruments kept at the NM-ČMH with earliest dating from 1790 (inv. no. E 3008), 1791 (inv. no. E 467), and 1793 (inv. no. E 464) do not have it. Beginning with the instrument at the NMM Vermillion made in 1793, all of the later specimens are decorated. With the aid of this design innovation, we are able to date more precisely two basset horns without stamps, which have been attributed to Doleisch on the basis of their structural and design characteristics. The first is a basset horn at the NM-ČMH, inv. no. E 476. The instrument does not have decorated rings, and it has a relatively archaic design for the a flat/e flat ${ }^{2}$ key. Therefore, we assume that it was made before 1793. A second basset horn without a stamp is the instrument in the collection of the Händel-Haus in the German city Halle (hereinafter the Händel-Haus), which already has decorated wooden rings, so it was apparently made in 1793 or later. ${ }^{28}$

27) These were also used somewhat later by Franz Strobach, who apparently learned to make basset horns in Franz Doleisch's workshop. See: ŠEBESTA 2009, op. cit. in footnote no. 4.

28)HEYDE, Herbert: Katalogzu denSammlungen des Händel-Hauses in Halle.7. Teil: Musikinstrumentensammlung: Blasinstrumente, Orgeln, Harmoniums, Händel-Haus, Halle 1980, pp. 224-225 (hereinafter HEYDE 1980). 
Another variable feature of the design of Doleisch's basset horns is the joining of the bottom keyed section (stock) with the book into an integral joint, which is found on older instruments, while the joints in question are separate on the newer specimens (1796-1803). The only exception is the earliest basset horn from 1790 (NM- ČMH, inv. no. E 3008), which has the joints separate in spite of the instrument's earlier date of manufacture. The brass protective covers on the bottom keys are also decisive for more precisely dating Doleisch's basset horns. These are missing only from the earliest instruments dated from 1790 to 1793, while the later basset horns dated from 1796 to 1803 have them.

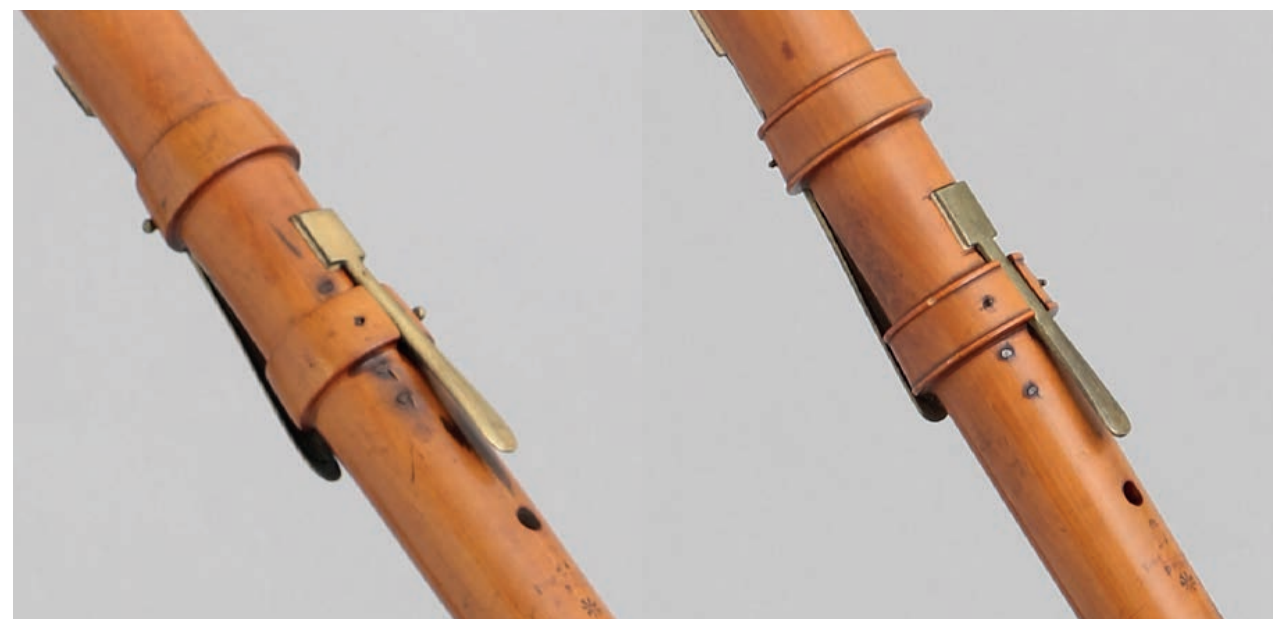

Left-hand joint of instruments without and with decoration of wooden rings NM-ČMH E 467, NM-ČMH E 466 (left to right) ๑) Jan Kř́žženecký

An important structural aspect of Doleisch's basset horn concept is the bore diameter inside the tube. Viennese instrument makers like Theodor Lotz or Raymund Griesbacher made their basset horns with a much wider bore diameter than clarinets (basset horns 15.4-15.9 mm, clarinets ca. $14.5-14.9 \mathrm{~mm}){ }^{29}$ In this way, they were reacting to the fact that a basset horn had a much longer tube than a clarinet. Influenced by the practice of German instrument makers, Doleisch chose to use the same bore diameter for basset horns as for clarinets (ca. 13.5-14.2 mm). The result was a tone with more concentrated colour and relatively stable intonation for the shakier notes produced by the "fork fingerings": $b$ flat, $f$, eflat $t^{1}, b$ flat $^{2}$, or the intonation and sound of the note $f^{1}$. The disadvantage was a dynamically subtler sound suitable for chamber music in smaller venues. The Viennese basset horn with its wider bore was more suited to the orchestra because it produced a larger, dynamically stronger tone. They were also preferred by the clarinettist Johann H. Backofen, who

29) HOEPRICH, Eric: $\mathcal{A}$ Trio of Basset Horns by Theodor Lotz, The Galpin Society Journal, 1997, no. 50, pp. 228-236. 
regarded them as the best. ${ }^{30}$ By contrast, it seems that the "clarinet-style" bore of Doleisch's basset horns was almost too narrow. Drawbacks included a reduced differentiation of colour in comparison with clarinet tone and the less penetrating sound of the bottom "basset" notes.

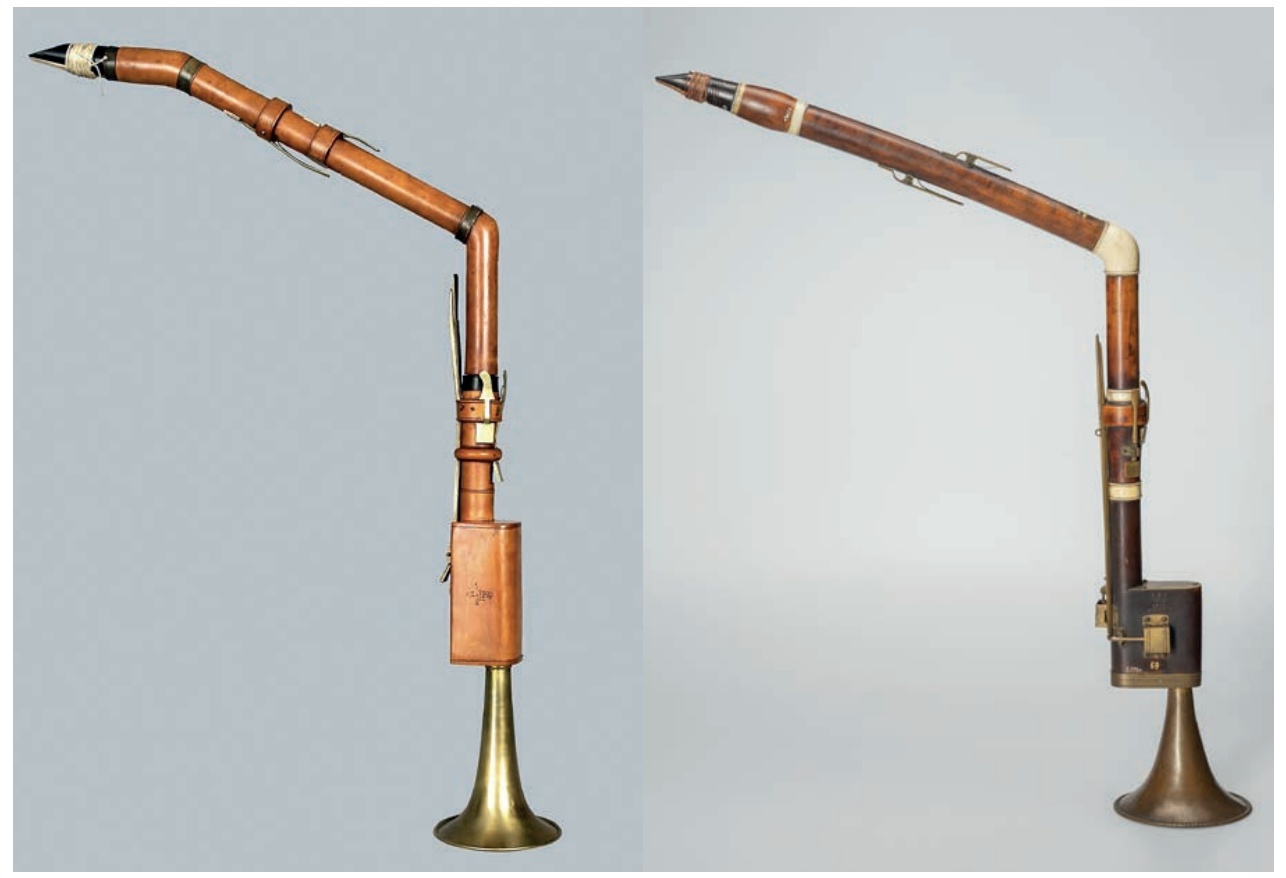

A Doleisch model and a basset horn made by Theodor Lotz

NMM Vermillion 3541, NM-ČMH E 1365 (left to right)

(c) NMM Vermillion, Creative Dreamers Production s.r.o.

\section{Number and design of keys}

Doleisch made basset horns with a constant number of keys installed in wooden rings and formed in the shape of a square. The total quantity depended on the number of basset keys, while the remaining configuration did not change. The total number of original keys varied from seven to nine. Originally, the seven-keyed models have just one basset key (for the note $c$ ). The specimens of this type of basset horn date from 1790 (NM-ČMH, inv. no. E 3008), ca. 1792 (Händel-Haus, inv. no. MS-406), and 1798 (PK, inv. no. M I/42, M I/43). The eight-keyed models have two basset keys for the notes $d$ and $c$. Six basset horns represent this stage of development: three from the NM-ČMH (inv. nos. E 467, E 464, E 476); two from two American collections: NMM Vermillion (inv. no. 3541) and Aurand-CM Michigan (without inventory number); and one from the MMP (inv. no. H 189529/001). We find the most advanced basset horn design with three basset keys for $e$ flat, $d$, and $c$ on four instruments: in the Brussels collection (MIM, inv. no.

30) "Die besten mir bekannten Bassethörner sind die Wiener, ...". BACKOFEN 1803, op. cit. in footnote no. 24, p. 36. 
MIM 938), PK (inv. no. M I/42), NM-ČMH (inv. no. E 466), and RCM (inv. no. 90). According to $\mathrm{N}$. Shackleton, those instruments are the earliest basset horns with a basset $e$ flat key. ${ }^{31}$ Additional keys, expanding the number from 10 to 13, are set in brass saddles, and they probably are not original. Of Doleisch's preserved basset horns with exclusively original keys, there are four sevenkeyed models with a partially diatonic basset register, six eight-keyed models with a complete diatonic basset register, and four nine-keyed specimens with a semi-chromatic basset register.

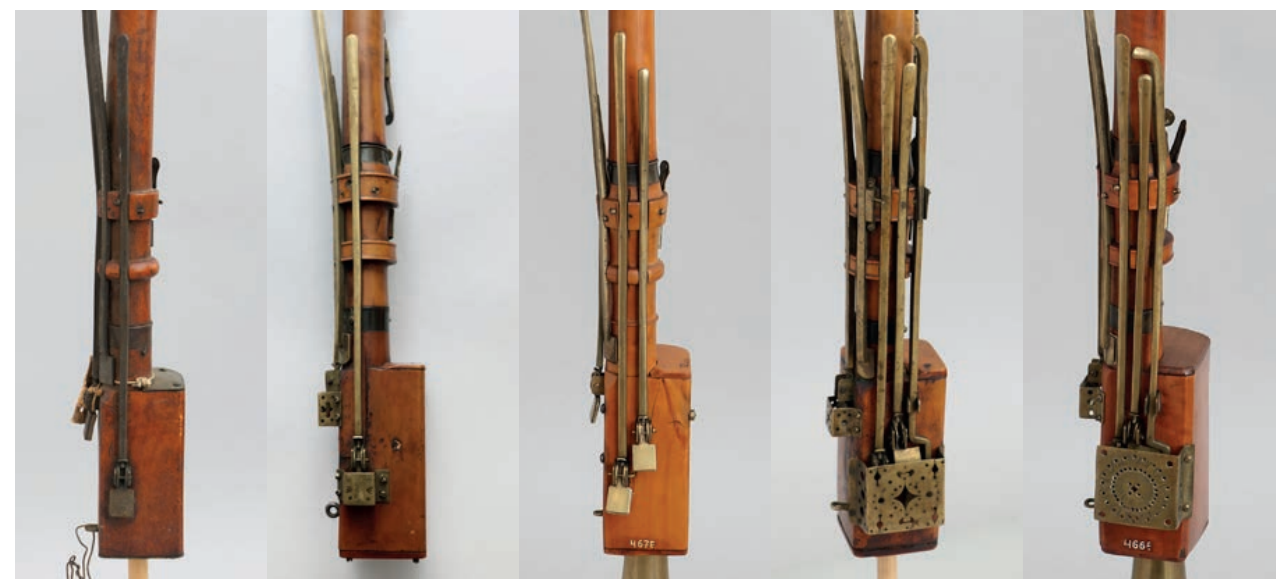

Basset horn keys: models with one (NM-ČMH E 3008, PK M I/43), two (NM-ČMHE 467), and three basset keys (PK M I/ 42, NM-ČMH E 466)

๑) Jan Kř́ženecký

In the design of the keys for Doleisch's basset horns, we also find a great difference of length for the two open basset keys (the notes $d, c$ ) in the upper touch-key levers, which would be awkward if the instrument were to be held in the middle between the player's legs. On the other hand, by twisting the bottom half of the instrument to the right of the player's body (right leg), the two keys in question become easy to use. Corresponding to that position is the placement of a brass eyelet for a cord on the left side of the book, used for holding the instrument in place while playing sitting down. Doleisch clearly set up the ergonomics of the keyed sections so that the upper half of the instrument was held parallel to the player's body, and at the knee the bottom part of the basset horn turned to the right of his body. We see a different approach with the basset horn in the collection of the RCM, which is designed to be played held in the centre. ${ }^{32}$ The levers for operating all three basset keys are equally long, and an eyelet for a cord is positioned in the middle of the bottom part of the book in order make all of the parts comfortable for players holding the instrument in the middle position.

31) SHACKLETON, Nicholas: The Earliest Basset Horns, The Galpin Society Journal, no. 40, 1987, p. 12 (hereinafter SHACKLETON 1987). The presence of a basset $e$ flat key is of pivotal importance for a chromatic basset register with full musical utility. The original diatonic basset register with only the notes $d$ and $c$ greatly limited the use of the basset horn for music in different keys.

32) There are two eyelets on the basset horn in the MMP collection: one for playing the instrument to the right of the player and the other for its central location. 


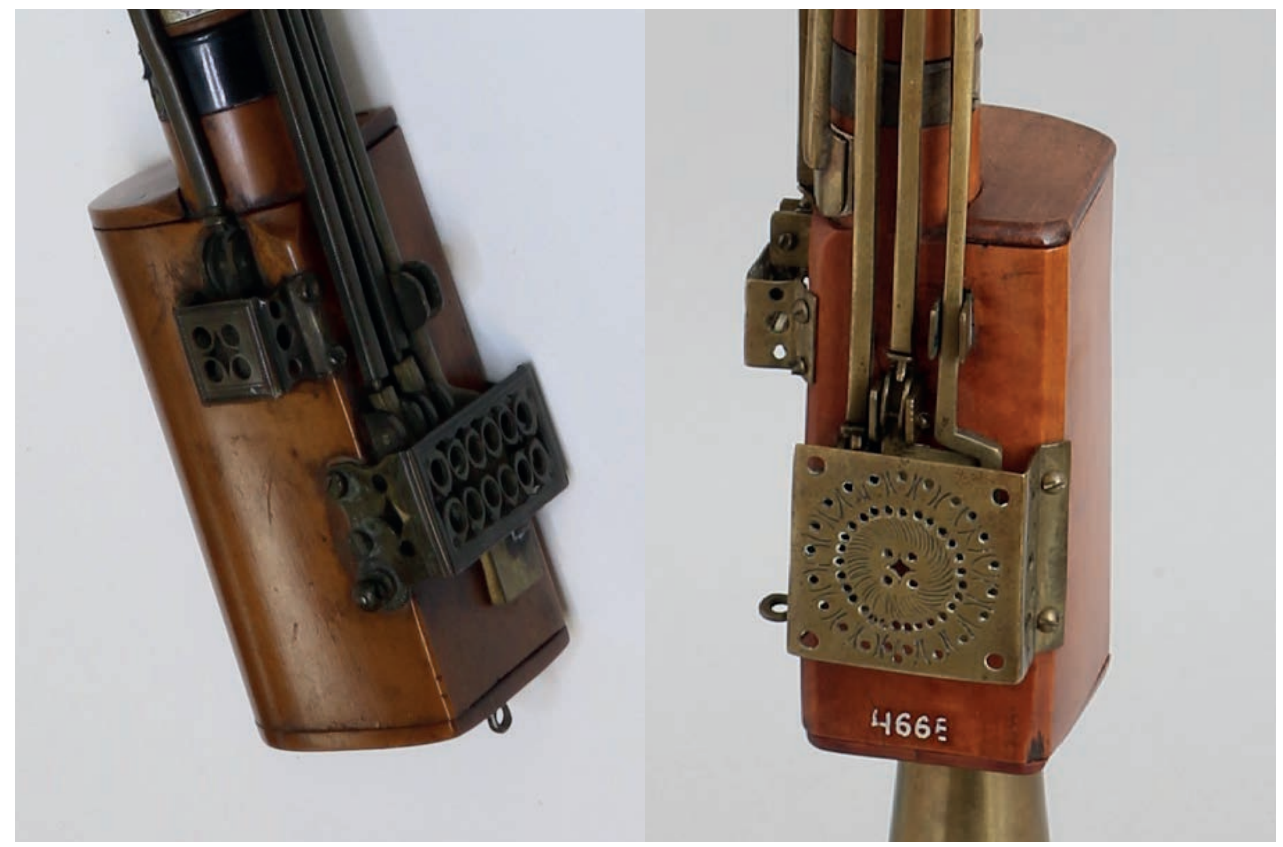

Different placements of the eyelet for the cord for suspending a basset horn RCM 90, NM-ČMH E 466 (c) RCM, Jan Kř́rženecký

In view of the date of their manufacture, it is surprising that as many as four of Doleisch's basset horns were made with just one basset key. Their production after 1790 seems developmentally anachronistic because basset horns without basset keys for the note $d$ were not commonly made at that time. In the case of the basset horns from 1798 from the PK collection, there may be a different reason for having just one basset key. ${ }^{33}$ In their case, it was apparently assumed that of the three basset horns in the set, two of them would not be used for playing the bottom part. For this purpose, only the basset horn with the inventory number $\mathrm{M} \mathrm{I} / 42$ with three basset keys for the notes $e$ flat, $d$, and $c$ was used to play the lowest part in a trio. The other two basset horns were played in the higher part of their range, where basset keys were not needed. In our opinion, this is why they have only one basset key for the note $c$. The absence of basset keys for $d$ and $e$ flat greatly shorted the time needed for their manufacturing and significantly lowered the purchase price. ${ }^{34}$ Basset horns were very expensive in general,

33) On the basis of the unusual $G$ tuning and the trademark (with the same year of manufacture), we believe that these three instruments were made as a matched set. Besides the name, location, and dating, these instruments are also marked with the numerals 1,2 , and 3 . Corresponding to these numerals is the number of stars beneath the trademark. The parts were individually numbered so that the parts of two or three instruments (manufactured as a set for one customer) would not be interchanged, thereby altering their musical properties. We also find the practice of numbering basset horns with other instrument makers such as Franz Strobach and Johann Theodor Lotz.

34) ŠEBESTA, Róbert: Basetové rohy prešporskej firmy Schöllnast (Basset horns by the Schöllnasts in Pressburg), Academy of Performing Arts, Bratislava 2019, p. 57. 
and the customer certainly appreciated the option of lowering the total price by reducing the number of basset keys on two of the three instruments. We do not know the reason for the absence of a $d$ basset key on the other basset horns with one basset key from the year 1790 (NM- ČMH, inv. no. E 3008) and from ca. 1792 (Händel-Haus, inv. no. MS-406). It is certain that this greatly limited their musical utility in the bottom register.

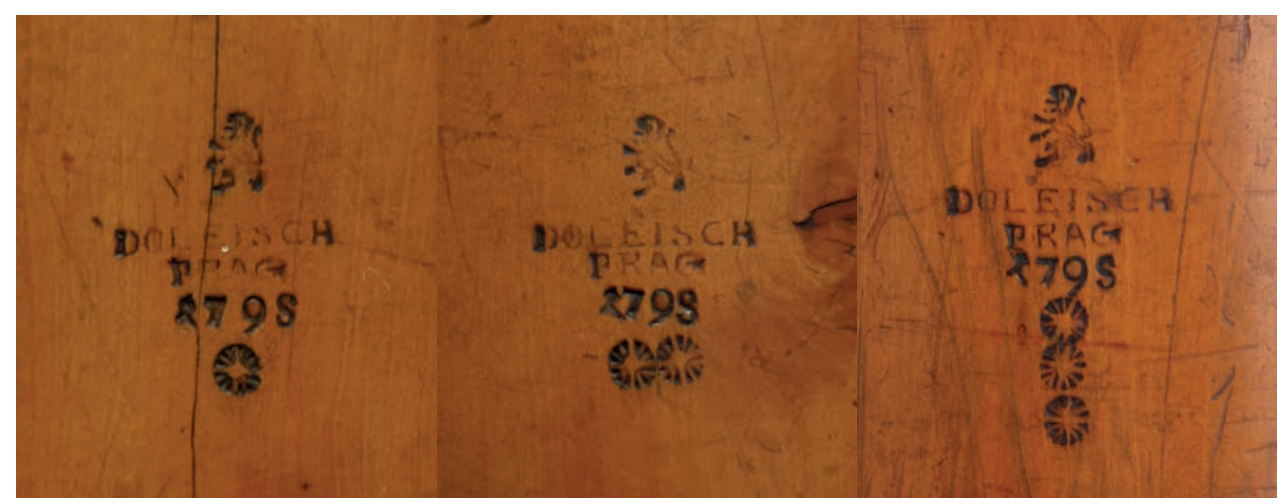

Trademarks of three Doleisch basset horns

from the Prague Conservatoire collection made in 1798 as a set PK M I/44, PK M I/43, PK M I/42

(c) Jan Kř́žzenecký

The "oboe-style" placement of the a flat/e flat and $f / c^{2}$ keys is also indicative of certain contacts between Czech and German instrument makers. This placement is the opposite of what was used on period clarinets, and it greatly complicates playing on both instruments, especially when alternating between them quickly like in operas, etc. We also find this anachronism with most of the basset horns of German provenance from this period. Viennese instrument makers such as Johann Theodor Lotz, Raymund Griesbacher, or Johann Baptist Merklein made their basset horns with the a flat/e flat $^{2}$ and $f / c^{2}$ keys in the same position as on clarinets, which made alternating between the two instruments far easier.

In the opinion of the authors of this study, the development of the design of Doleisch's basset horns can be seen most clearly from the lever that operates the a flat/e flat ${ }^{2}$ key. A "butterfly key" is found on the earliest basset horns from 1790 (NM-ČMH, inv. no. E 3008)

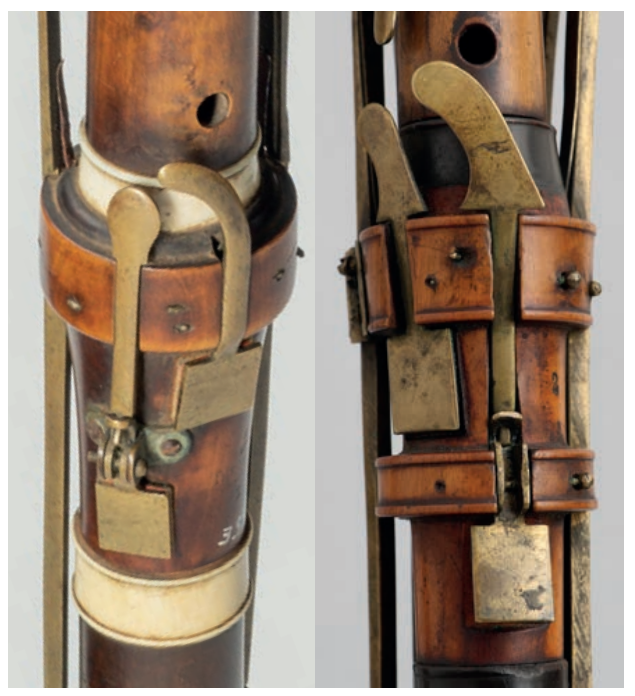

Opposite placement of the keys a flat / e flat ${ }^{2}$ and $f / c^{2}$ on Lotz and Doleisch basset horns NM-ČMHE 1365, PK M I/42

(c) Creative Dreamers Production s.r.o., Jan Kř́iženecký 
and 1791 (NM-ČMH, inv. no. E 467). The design of the lever for the $a$ flat/e flat $^{2}$ key on the basset horn from ca. 1793 (NM-ČMH, inv. no. E 476) is only slightly more modern. On the other hand, the most modern design in this respect is found on Doleisch's newest basset horn in the RCM collection, where the design of the a flat/e flat ${ }^{2}$ key is the same as for the other keys.

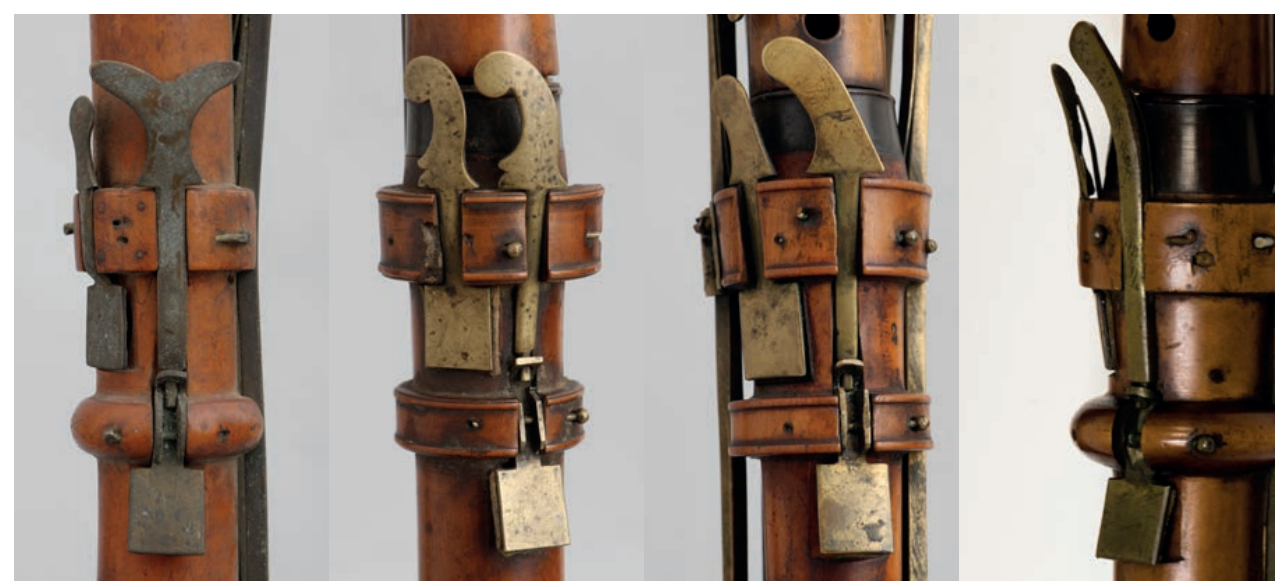

Basset horns from 1790 (NM-ČMH E 3008), ca. 1792-1793 (NM-ČMH E 476), 1798 (PK M I/42), 1803 (RCM 90) (left to right)

(c) Jan Kříženecký, RCM

\section{Trademark}

Doleisch's trademark is a source of important information. Especially invaluable is the indication of the year of the instrument's manufacture on the trademark, which allows us to determine the exact chronology of structural and design innovations. The constant features of Doleisch's trademark are a star, the maker's name, the location, and the Bohemian lion. ${ }^{35}$ A variable element is the marking of individual parts with numbers in cases when several identical instruments were supplied to a single client.

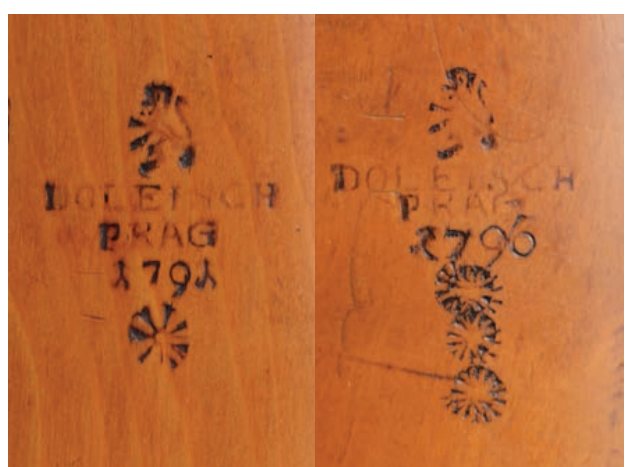

Doleisch trademarks with different years NM-ČMH E 467, NM-ČMH E 466 (c) Jan Křriženecký In such cases, each part of a particular instrument is marked with the same numeral or with the corresponding number of stars (one, two, or three) to prevent parts from being interchanged. We find the numbering of parts mainly on basset horns, which were routinely

35) On the basset horns at Aurand CM Michigan, RCM, and MMP, the trademark bears the symbol of a doubleheaded eagle instead of the Bohemian lion. 
supplied in series of two or three items. Franz Strobach and Theodor Lotz also employed the same practice. ${ }^{36}$

\section{Conclusion}

In the context of the making of woodwind instruments in the $18^{\text {th }}$ century, making basset horns was by far the most complicated process, and only the best makers attempted it. The difficulty was directly reflected by the time required for the production process, which was many times longer than that required for the other woodwind instruments of the period. This was primarily the case for models with a chromatic basset register, which Franz Doleisch the Elder was one of the first to make. His concept for the basset horn with a narrow bore diameter represents an alternative to the structure and sound of the Viennese model. The fourteen preserved basset horns built from 1790 to 1803 show that he was long involved in the making of the instruments and their development. ${ }^{37}$ There is no doubt that in terms of quality of craftsmanship, these instruments are among the best of the $18^{\text {th }}$ century, but the current status of research does not reflect this fact. No one has yet dealt comprehensively with Doleisch's instrument production. Despite the several research studies mentioned above, there is no entry for Franz Doleisch even in the newest edition of The Grove Dictionary of Musical Instruments (2014)..$^{38}$ That is a further reason for the creation of this study. The goal is not only to compile the already published information about the instrument maker, but also, in particular, to present the findings of the first phase of research focused on Doleisch's preserved basset horns in instrument collections in the Czech Republic and around the world, with information about their design specifications. The next phase will focus on archival work, leading to the clarification of biographical information about Doleisch's life and career, and the results of that research should contribute to the status our knowledge of woodwind instrument manufacturers from the turn of the $18^{\text {th }}$ and $19^{\text {th }}$ centuries in central Europe. Last but not least, there should be addition of information about more of Doleisch's preserved basset horns as well as other types of instruments that he made. Already at this stage, the results of incomplete research clearly show that Franz Doleisch the Elder is rightly regarded as an elite European instrument maker of the latter half of the $18^{\text {th }}$ century.

36) ŠEBESTA, Róbert: Strobach basset horn production in the light of new biographical discoveries, in: Geschichte, Bauweise und Repertoire der Klarinetteninstrumente. Michaelsteiner Konferenzberichte, Band 77, eds. Monika Lustig - Boje E. Hans Schmuhl, Kloster Michaelstein - Musikakademie/Museum, Augsburg Michaelstein 2008, pp. 113-121.

37) Doleisch only made angled basset horns with multiple separate sections and with a book. With the exception of a single instrument, F. Strobach only made basset horns with the body segmented by only a single joint, without a book, and with a spherical bell.

38) The Grove Dictionary of Musical Instruments, ed. Laurence Libin, vol. 2, Oxford University Press, $2^{\text {nd }}$ edition, 2014. 


\section{List of preserved instruments}

1.

\section{Basset horn in $\mathrm{F}$, made in 1790}

The mouthpiece and bell are missing.

Trademark: Bohemian lion / DOLEISCH / PRAG / 1790 / * *

Location and collection: NM-ČMH, inv. no. E 3008

Design and material: angled model with a book, diatonic basset register, boxwood, horn rings, bore diameter $13.6 \mathrm{~mm}$

Keys: 8 square-shaped brass keys, 7 original keys $a^{1}, b^{1}$ (register key), a flat/e flat ${ }^{2}, f / c^{2}$, fsharp/c sharp ${ }^{2}, e / b^{l}$, basset $c, 1$ extra key: $c$ sharp $/ g$ sharp ${ }^{2}$

Special features: straight barrel, separate knee (117 angle), metal covers on the book, the lever for operating the a flat/e flat ${ }^{2} \mathrm{key}$ is in the archaic shape of a butterfly. The mouthpiece is probably not original (bore $14.5 \mathrm{~mm}$ ).

\section{2.}

Basset horn in $\mathrm{F}$, made in 1791

Complete

Trademark: Bohemian lion / DOLEISCH / PRAG / 1791 / *

Location and collection: NM-ČMH, inv. no. E 467

Design and material: angled model with a book, angled barrel ( $155^{\circ}$ angle), integral knee (117 ${ }^{\circ}$ angle), diatonic basset register, boxwood, horn rings, circular brass bell, diatonic basset register, bore diameter 13.8-14.4 mm, total length of the instrument without the bell $985 \mathrm{~mm}$ Keys: 8 square-shaped brass keys: $a^{1}, b^{1}$, a flat $/$ flat ${ }^{2}, f / c^{2}, f$ sharp $/ c$ sharp ${ }^{2}, e / b^{1}$, basset $d$, basset $c$

Special features: the bottom section with keys (stock) is joined to the book as an integral joint. The book is closed at the top and bottom by wooden covers. The basset keys lack protective covers, and the lever for operating the $a$ flat/e flat ${ }^{2}$ key is in the archaic shape of a butterfly. Bibliography: Průvodce výstavou české hudební nástroje minulosti v brevvnovském klášteře sv. Markéty (A Guide to the Exhibition of Czech Musical Instruments of the Past at St Margaret's Convent in Břevnov), Národní muzeum, Praha 1950, p. 33 (hereinafter Průvodce); LANGWILL 1972, p. 37; CULKA, Zdeněk - RUTOVÁ, Milada - ŠERÝCH, Jaroslav: Muzeum hudebních nástrojů. Katalog stálé expozice hudebnich nástrojů hudebního oddělení Národního muzea v Praze (Museum of Musical Instruments: A Catalogue of the Musical Instrument Exhibit of the Music Department of the National Museum in Prague), $2^{\text {nd }}$ edition, Národní muzeum, Praha 1973, p. 39; LANGWILL 1980, p. 41; YOUNG 1993, p. 65; BRECHLIČUKOVÁ, Irena: Franz Strobach - „unbekannt“ nejen v Karlových Varech. Hudební nástrojárství a kultura v Čechách na prélomu 18. a 19. století (Franz Strobach - "Unknown" Not Only in Karlovy Vary. Musical Instrument Making and Culture in Bohemia at the Turn of the $18^{\text {th }}$ and $19^{\text {th }}$ Centuries), master's thesis, Faculty of Arts, Masaryk University, Brno 2003, pp. 10, 41, 43, 54 (hereinafter BRECHLIČUKOVÁ 2003); GRASS-DEMUS 2004, p. 254; PIDDOCKE 2012, pp. $415-416$. 
3.

Basset horn in F, made in ca. 1792

The mouthpiece and bell are missing.

Trademark: no trademark, attributed

Location and collection: NM- ̌̌MH, inv. no. E 476

Design and material: angled model with a book, boxwood, horn rings, angled barrel $\left(155^{\circ}\right)$, integral knee $\left(117^{\circ}\right)$, diatonic basset register, bore diameter $13.8 \mathrm{~mm}$, total length of the instrument without the bell $985 \mathrm{~mm}$

Keys: 8 square-shaped brass keys: $a^{1}, b^{1}$, a flat/e flat ${ }^{2}, f / c^{2}, f$ sharp $/ c$ sharp ${ }^{2}, e / b^{1}$, basset $d$, basset $c$ Special features: The instrument has brass fittings on the top and bottom of the book. All of the rings are decorated. The bottom section with keys is attached to the book as an integral joint. The $f$ sharp $/ c$ sharp ${ }^{2}$ and basset $c$ keys are missing, and the levers for operating the a flat/e flat ${ }^{2}$ and $f / c^{2}$ keys are archaic in design.

Bibliography: SHACKLETON 1987, p. 17, footnote no. 12; RICE 2009, pp. 157-158.

\section{4.}

Basset horn in F, made in ca. 1793

The bell is not original.

Trademark: no trademark or year of manufacture, attributed

Location and collection: Händel-Haus, inv. no. MS-406

Design and material: angled model with a book, angled barrel $\left(155^{\circ}\right)$, integral knee $\left(117^{\circ}\right)$, boxwood, horn rings, brass keys, incomplete diatonic basset register, overall length of the instrument from the barrel to the end of the book $891 \mathrm{~mm}$, bore diameter $13.8 \mathrm{~mm}$ Keys: 7 flat, square-shaped brass keys: $a^{1}, b^{1}$, a flat/e $f l a t^{2}, f / c^{2}, f$ sharp $/ c$ sharp ${ }^{2}, e / b^{1}$, basset $c$ Special features: the instrument lacks protective covers on the bottom keys. The rings are decorated. The instrument has only one basset $c$ key.

Bibliography: HEYDE 1980, pp. 224-225; RICE 2009, p. 136.

5.

\section{Basset horn in F, made in 1793}

Complete

Trademark: * Bohemian lion / DOLEISCH / PRAG / 1793 / *

Location and collection: NM-ČMH, inv. no. E 464

Design and material: angled model with a book, angled barrel $\left(155^{\circ}\right)$, integral knee $\left(117^{\circ}\right)$, boxwood, horn rings, diatonic basset register

Keys: 8 square-shaped brass keys: $a^{1}, b^{1}$, a flat/e flat ${ }^{2}, f / c^{2}, f$ sharp $/ c s h a r p^{2}, e / b^{1}$, basset $d$, basset $c$

Special features: the instrument was written off from the collection in 1997, the bottom basset keys lack protective covers, the bottom section with keys (stock) is joined to the book as an integral joint. 
Bibliography: LANGWILL 1972, p. 37; LANGWILL 1980, p. 41; YOUNG 1993, p. 65; GRASS, Thomas - DEMUS, Dietrich: Das Bassetthorn. Seine Entwicklung und seine Musik, Books on Demand GmbH, Norderstedt 2002 (1 $1^{\text {st }}$ edition), p. 210; RICE 2009, p. 135.

6.

Basset horn in F, made in 1793

Complete

Trademark: Bohemian lion / DOLEISCH / PRAG / 1793 / *

Location and collection: NMM Vermillion, inv. no. 3541

Design and material: angled model with a book, angled barrel $\left(155^{\circ}\right)$, integral knee $\left(117^{\circ}\right)$, boxwood, horn rings, diatonic basset register, bore diameter $13.0 \mathrm{~mm}$

Keys: 8 square-shaped brass keys: $a^{1}, b^{1}$, a flat/e $f l a t^{2}, f / c^{2}, f$ sharp $/ c$ sharp ${ }^{2}, e / b^{1}$, basset $d$, basset $c$

Special features: the bottom section with keys (stock) is joined to the book as an integral joint. The book has wooden covers on the top and bottom. The bottom keys lack protective covers. The wooden rings on the upper part are decorated.

Bibliography: HOEPRICH 2008, p. 241, fig. 10.4; RICE 2009, p. 135.

Retrieved from: http://collections.nmmusd.org/Exhibitions/Muzika/Muzikabassethorn.html [accessed on 9 Apr. 2021].

\section{7.}

Basset horn in F, made in 1796

Complete

Trademark: Bohemian lion / DOLEISCH / PRAG / 1796 / *

Location and collection: NM-ČMH, inv. no. E 466

Design and material: angled model with a book, angled barrel $\left(155^{\circ}\right)$, integral knee $\left(117^{\circ}\right)$, boxwood, horn rings, partially chromatic basset register, bore diameter $13.2-13.3 \mathrm{~mm}$, total length of the instrument without the bell $980 \mathrm{~mm}$

Keys: 9 square-shaped brass keys: $a^{1}, b^{1}$, a flat/e $f l a t^{2}, f / c^{2}, f$ sharp $/ c$ sharp ${ }^{2}, e / b^{1}$, basset $e$ flat, basset $d$ and $c$

Special features: The bottom keys $e / b$, basset $e$ flat, $d$, and $c$ have protective covers. The wooden rings on the upper section with keys are decorated.

Bibliography: Průvodce, p. 33; LANGWILL 1972, p. 37; KELLER 1977, appendix with photographs (fifth unnumbered photograph); LANGWILL 1980, p. 41; KELLER, Jindřich: Sólo pro dva mistry (o hudebních nástrojich), Albatros, Praha 1982, p. 75; SHACKLETON 1987, p. 22, footnote no. 35; YOUNG 1993, p. 65; ČÍŽEK, Bohuslav: Hudebni nástroje evropské hudebni kultury (Musical Instruments of European Musical Culture), Aventinum, Praha 2002, p. 130; BRECHLIČUKOVÁ 2003, 41, 43; GRASS-DEMUS 2004, p. 255; RICE 2009, p. 136; PIDDOCKE 2012, pp. 94, 147, 174-175.

8. Basset horn in F, made in 1797

The mouthpiece is missing.

Trademark: Bohemian lion / DOLEISCH / PRAG / 1797 /**** / 3 
Location and collection: MIM, inv. no. MIM 938

Design and material: angled model with a book, angled barrel $\left(155^{\circ}\right)$, integral knee $\left(117^{\circ}\right)$, boxwood, horn rings, bore diameter $13.8 \mathrm{~mm}$

Keys: 9 flat, square-shaped brass keys: $a^{1}, b^{1}$, a flat/e flat ${ }^{2}, f / c^{2}, f$ sharp $/ c$ sharp ${ }^{2}, e / b^{1}$, basset $e$ flat, basset $d$ and $c$

Special features: All of the rings are decorated. The book has wooden covers on the top and bottom. The bottom keys have protective covers. It probably comes from a set of three basset horns, in which it played the lowest voice.

Bibliography: GRASS-DEMUS 2004, p. 254; RICE 2009, p. 136.

Retrieved from: https://www.carmentis.be:443/eMP/eMuseumPlus?service=ExternalInterface\&module=collection\&objectId=120885\&viewType=detailView [accessed on 9 Apr. 2021].

\section{9.}

\section{Basset horn in F, made in 1798}

The bell is missing.

Trademark on the book: Bohemian lion / DOLEISCH / PRAG / 1798 / ** (on the other parts ${ }^{* * * *}$ ) Location and collection: PK, inv. no. M I/43

Design and material: angled model with a book, angled barrel $\left(155^{\circ}\right)$, integral knee $\left(117^{\circ}\right)$, boxwood, horn rings, partially diatonic basset register, bore diameter $13.1-13.8 \mathrm{~mm}$, total length without mouthpiece and bell $895 \mathrm{~mm}$

Keys: 10 square-shaped brass keys: 7 original: $a^{1}, b^{1}$, a flat/e flat ${ }^{2}, f / c^{2}, f$ sharp $/ c$ sharp ${ }^{2}, e / b^{1}$, basset $c$, additional keys: e flat $/$ b flat ${ }^{2}, c \operatorname{sharp}^{1} / g \operatorname{sharp}^{2}, b \mathrm{flat}^{1} / \mathrm{f}^{2}$

Special features: All of the instrument's rings are decorated.

Bibliography: ČÍŽEK 1981, p. 58; GRASS-DEMUS 2004, p. 263; RICE 2009, p. 136.

10.

\section{Basset horn in F, made in 1798}

The mouthpiece, barrel, upper section with keys, and bell are missing.

Trademark: 1 / Bohemian lion / DOLEISCH / PRAG / 1798 / *

Location and collection: PK, inv. no. M I/44

Design and material: angled model with a book, angled barrel $\left(155^{\circ}\right)$, integral knee $\left(117^{\circ}\right)$, boxwood, horn rings, partially diatonic basset register ( $c$ key only), bore diameter $13.7 \mathrm{~mm}$ (middle key part)

Keys: 6 flat, square-shaped brass keys, original keys: a flat $/$ e $f l a t^{2}, f / c^{2}, f$ sharp $/ c$ sharp ${ }^{2}, e / b^{1}$, basset $c$, extra key: $b$ flat $^{1} / f^{2}$

Special features: the instrument has decorated rings. The instrument's body has a right-hand joint and bottom section (stock) with keys and a book.

Bibliography: ČÍŽEK 1981, p. 58; GRASS-DEMUS 2004, p. 263; RICE 2009, pp. 157-158.

11.

\section{Basset horn in F, made in 1798}

The mouthpiece is missing. 
Trademark on the book: 2 / Bohemian lion / DOLEISCH / PRAG / 1798 / ****

Location and collection: PK, inv. no. M I/42

Design and material: angled model with a book, angled barrel $\left(155^{\circ}\right)$, integral knee $\left(117^{\circ}\right)$, boxwood, horn rings, partially chromatic basset register, bore diameter $13.8-14.4 \mathrm{~mm}$, total length without mouthpiece and bell $895 \mathrm{~mm}$

Keys: 12 flat, square-shaped brass keys: 9 original keys: $a^{1}, b^{1}$ (register key), a flat/e flat ${ }^{2}$, $f / c^{2}, f$ sharp $/ c s_{a r p}{ }^{2}, e / b^{1}$, basset $e$ flat, basset $d$, basset $c$, additional keys: $e$ flat $^{1} / b f l a t^{2}$, c sharp $1 / g$ sharp ${ }^{2}$, flat fl $^{2}$

Special features: the instrument has covers on the $e / b^{1}$ key and the basset $e$ flat, $d$, and $c$ keys. The rings are decorated.

Bibliography: ČÍŽEK 1981, p. 58; GRASS-DEMUS 2004, p. 254; RICE 2009, p. 136.

12.

\section{Basset horn in F, made in 1800}

Complete

Trademark: Double-headed eagle / DOLEISCH / PRAG / 1800 / ****

Location and collection: originally a private collection of Musical Instrumens by Dr. Charles Aurand in Tucson, Arizona, today part of the collection Michigan State University College of Music

Design and material: angled model with a book, angled barrel $\left(155^{\circ}\right)$, integral knee $\left(117^{\circ}\right)$, boxwood, horn rings, diatonic basset register

Keys: 13 square-shaped brass keys, original keys: $a, b^{1}$, a flat/e flat ${ }^{2}, f / c^{2}, f$ sharp $/ c$ sharp ${ }^{2}, e / b^{1}$, basset $d$, basset $c$, additional keys: $e s^{1} / b^{2}, c \operatorname{sharp}^{1} / g \operatorname{sharp}^{2}, g \operatorname{sharp}^{1}, a / b$ trill, $b \mathrm{flat}^{1} / f^{2}$

Special features: The instrument has decorated rings and protective coverings on the bottom keys.

Bibliography: RICE 2009, pp. 157-158.

Retrieved from: https://www.music.msu.edu/news/something-old-something-new [accessed on 9 Apr. 2021]; Aurand Collection of Musical Instruments, College of Music Michigan State University, collection catalog, p. 4 (last update on 1 Oct. 2021); https://www.music.msu.edu/assets/Aurand_ Collection_of_Musical_Instruments_10-1-21.pdf [accessed on 11 Oct. 2021].

13.

\section{Basset horn in $\mathrm{F}$, made in 1803}

The mouthpiece and bell are missing, and the barrel is not original.

Trademark: Double-headed eagle / DOLEISCH / PRAG / 1803 / *** / F

Location and collection: RCM, inv. no. 90

Design and material: model with a book, angled barrel $\left(155^{\circ}\right)$, integral knee $\left(117^{\circ}\right)$, boxwood, horn rings, partially chromatic basset register, bore diameter $13.2 \mathrm{~mm}$

Keys: 9 square-shaped brass keys: $a, b^{1}$, a flat/e $f l a t^{2}, f / c^{2}, f$ sharp $/ c$ sharp ${ }^{2}$, e/ $b^{1}$, basset $e$ flat, basset $d$, basset $c$

Special features: the keys have metal pivots inserted in wooden blocks. The instrument has decorated wooden rings on the upper section with keys. Unlike the other instruments, the 
basset key-levers are of equal length. The levers for the keys $f$ sharp/c sharp ${ }^{2}$ and $e / b^{l}$ are shortened. On the book there are two brass eyelets for suspending the instrument using a cord when playing while standing: one on the left side of the book for suspending the instrument to the right of the player's body and a second one on the bottom of the book for holding the instrument in the central position.

Bibliography: RICE 2009, pp. 157-158.

Retrieved from: http://museumcollections.rcm.ac.uk/collection/Details/collect/1227 [accessed on 9 Apr. 2021].

14.

\section{Basset horn in F, made in 1803}

The mouthpiece, top section with keys, and bell are missing.

Trademark: Double-headed eagle / DOLEISCH / PRAG / 1803 /* / F

Location and collection: MMP, inv. no. H 189 529/001

Design and material: model with a book, angled barrel $\left(155^{\circ}\right)$, integral knee $\left(117^{\circ}\right)$, boxwood, horn ring, diatonic basset register

Keys: 2 square-shaped brass keys: a flat $/ e$ flat ${ }^{2}$ and $f / c^{2}$. The key for $f$ sharp $/ c$ sharp ${ }^{2}$ is missing, as is the long control lever for the key $e / b^{l}$ and basset keys $d$ and $c$. In its original, complete state, the instrument also had $a^{l}$ and $b^{l}$ keys on the upper section with keys for a total of 6 keys.

Special features: the book has two brass eyelets: one on the left side of the book for suspending the instrument to the right of the player's body, and a second one on the bottom of the book for holding the instrument in the central position. The design of the a flat $/ e$ flat ${ }^{2}$ and $f / c^{2}$ keys is not as advanced as on Doleisch's basset horn in the RCM collection. The instrument does not have decorated wooden rings. The horn ring on the middle section with keys is missing.

Bibliography: YOUNG 1993, p. 65.

Address: Róbert Šebesta, Vysoká škola múzických umení, Zochova 1, 81103 Bratislava, Slovakia E-mail: rsebesta@vsmu.sk

Address: Daniela Kotašová, České muzeum hudby, Karmelitská 2, 11800 Praha 1, Czech Republic E-mail: daniela.kotasova@nm.cz 


\section{Basetové rohy Franza}

\section{Doleischa v českých a svetových nástrojových zbierkach}

\section{Róbert Šebesta - Daniela Kotašová}

Basetový roh je v súčasnosti pomerne málo známym nástrojom a to aj napriek jeho významnému umeleckému uplatneniu vo vrcholných dielach Wolfganga Amadea Mozarta. ${ }^{1}$ Tento jednoplátkový nástroj z rodiny klarinetov sa staval väčšinou v F ladení a svojou altovo-tenorovou polohou zastával pozíciu stredného melodického hlasu. ${ }^{2}$ Podla dobového vyjadrenia rakúskeho hudobníka, zrejme aj hráča na basetovom rohu, dirigenta a hudobného spisovatela Franza Xavera Glöggla (1764-1839), „Bassetthorn (corno Bassetto) ist ein sehr angenehmes Blasinstrument von Holz; welches ums J. 1760 von einem Deutschen erfunden, und im J. 1782 zu mehrerer Vollkommenheit durch Theodor Lotz gebracht wurde “3 Vd'aka následnému rozšíreniu do strednej Európy jeho d’alší vývoj zásadne ovplyvnili nástrojári pôsobiaci na území dnešnej Českej a Slovenskej republiky. Konštrukčné inovácie Theodora Lotza (1746-1792), Franza Doleischa I. (1748/49-1805) a Franza Strobacha (cca 1769-1812) sa nezmazatelne zapísali do histórie basetového rohu a sú klúčovou súčastou jeho vývoja. Zatial čo basetové rohy Theodora Lotza a Franza Strobacha boli v uplynulých rokoch podrobené detailnému

Predložená práca vznikla za finančnej podpory Ministerstva kultúry ČR v rámci inštitucionálneho financovania dlhodobého koncepčného rozvoja výzkumnej organizácie Národní muzeum

(DKRVO 2019-2023/21.I.a, 00023272).

1) Chceli by sme sa pod'akovat' všetkým tým, ktorí prispeli k získavaniu podkladov k našej štúdii svojou radou, pripomienkou alebo inou cennou pomocou k vzniku tohto článku. Boli to Albert R. Rice, Gabrielle RossiRognoni (Royal College of Music Museum, London, d'alej RCM), Richard Martin (RCM), Géry Dumoulin (Musée des Instruments de Musique, Bruxelles, d'alej MIM), D. Check Reeves (National Music Museum vo Vermillione - University of South Dakota, d'alej NMM Vermillion), Mingzhe Wang (Michigan State University College of Music, pôvodne súkromná zbierka dr. Charlesa Auranda v Tucsone v Arizone (d'alej Aurand CM Michigan), Jakub Kydlíček a Michaela Hejlová (Pražská konzervatoř, d'alej PK), Kateřina Krylová a Magdaléna Šustová (Muzeum hlavního města Prahy, d'alej MMP) a kolegovia z Národního muzea - Českého muzea hudby v Prahe (d'alej NM-ČMH).

2) Podrobnosti viz SHACKLETON, Nicolas: Basset-horn [heslo]. Dostupné z: https://www.oxfordmusiconline. com/grovemusic [cit. 14. 4. 2021].

3) GLÖGGL, Franz Xaver: Allgemeines musikalisches Lexikon, in vier Abtheilungen: Aus den bewährtesten Schriftstellern, Selbstverlag, Linz 1812, 1. Abtheilung, s. 46.

Pravdepodobnost' informácie, že basetový roh bol vynájdený v Nemecku okolo roku 1760 sa zvyšuje tým, že otec F. X. Glöggla, Joseph Glöggl, bol známý jako jeden z prvých učitel'ov hry na basetovom rohu. Na tento fakt upozornil A. Rice v roku 2009. Porov. RICE, Albert R.: From the Clarinet D’Amour to Contra Bass: $A$ History of Large Size Clarinets, 1740-1860, Oxford University Press, New York 2009, s. 101 (d'alej RICE 2009). 
organologickému výskumu, ${ }^{4}$ nástrojárska produkcia pražského výrobcu drevených dychových nástrojov Franza Doleischa I. ešte čaká na komplexné zhodnotenie.

Z existujúcej historickej spisby nachádzame najstaršiu zmienku o Doleischovi v siedmom zošite niekol'kozväzkového historiografického diela Josepha Antona von Rieggera, v ktorom Gottfried Johann Dlabacž podáva stručnú hodnotiacu informáciu už v roku 1788: „Dolegschy, ein berühmter Kunstdrechsler, macht die beßten Hoboes, Flauten, Klarinette und Fagots. " Charakterizuje ho ako slávneho nástrojára a najlepšieho výrobcu drevených dychových nástrojov, čo v plnej miere potvrdzuje aj kvalita jeho zachovaných nástrojov. Chýbajúca zmienka o basetovom rohu môže naznačovat, že Doleisch ho v tomto čase ešte nevyrábal. Práca Ernsta Ludwiga Gerbera z roku 1812 už takmer doslova opakuje údaje publikované Dlabaczom z roku 1788. ${ }^{6}$ Dalšie hodnotenia Doleischovej nástrojárskej produkcie zaznamenávame až v 2. polovici 20. storočia. Prvým autorom, ktorý sa jej v novodobej ére podrobnejšie venoval, bol v 70. rokoch 20. storočia kurátor zbierky hudobných nástrojov pražského Národného múzea Jindřich Keller. Z Z jeho výskumov pochádzajú všetky doteraz známe biografické údaje o Franzovi Doleischovi I. a jeho synovi Franzovi Doleischovi II. Informácie čerpal predovšetkým z matričných záznamov, publikovaných v práci Antonína Podlahu v roku 1917. ${ }^{8}$ Zo zachovaných Doleischových nástrojov uvádza dva hoboje, dva klarinety a tri basetové rohy, ktoré zhodnotil ako najlepšie z produkcie českých nástrojárov. Na jeho výskum v čiastkových textoch nadviazal Bohuslav Čížek, ktorý doplnil Kellerov súpis Doleischových zachovaných basetových rohov o tri exempláre zo zbierky Pražského konzervatória. ${ }^{9}$ Zo zahraničnej lexikónovej databázy uvádza základné biografické a organologické informácie už v roku 1972

4) Porov. ŠEBESTA, Róbert - HOEPRICH, Eric: Franz Strobach: basset horns ef new biographical information, in: Journal of the American Musical Instrument Society (JAMIS), roč. 36, 2010, s. 58-77; ŠEBESTA, Róbert: Produkcia Strobachových basetových rohov vo svetle nových biografických poznatkov, Opus musicum, roč. 41, 2009, č. 3, s. 17-24 (d'alej ŠEBESTA 2009); ŠEBESTA, Róbert: Nástrojár Johann Theodor Lotz vo svetle historickej dokumentácie: najnovšie objavy a zhodnotenie, Clavibus unitis, roč. 5, 2016, s. 1-14. Dostupné z https://www. acecs.cz/media/cu_2016_05_sebesta.pdf [cit. 13. 5. 2021]; PIDDOCKE, Melanie Anne: Theodor Lotz: a biographical and organological study. Edinburgh Research Archive, The University of Edinburgh 2012 (d'alej PIDDOCKE 2012). Dostupné z https://era.ed.ac.uk/handle/1842/7707 [19. 3. 2021].

5) DLABACŽ, Johann Gottfried: Versuch eines Verzeichnisses der vorzüglichern Tonkünstler in oder aus Böhmen, in: Materialien zur alten und neuen Statistik von Böhmen, ed. Joseph Anton von Riegger, Heft VII, Kaspar Widtmann, Prag - Leipzig 1788, s. 162.

6) GERBER, Ernst Ludwig: Neues historisch-biographisches Lexikon der Tonkünstler, A. Kühmel, Leipzig 1812, 1. díl, sl. 9ll. Takmer rovnaký údaj uvádza tiež Dlabačov slovník z roku 1815, porov. DLABACŽ, Johann Gottfried: Allgemeines historisches Künstler-Lexikon für Böhmen und zum Theil auch für Mähren und Schlesien, Prag 1815, zväzok 1, sl. 333.

7) KELLER, Jindřich: Piśtělníci a trubaři. Pojednání o výrobě dechových hudebnich nástrojů v Čechách před rokem 1800, in: Sborník Národního muzea v Praze. Rad A, roč. 29, 1977, č. 4-5, s. 180, 199, 201, 204, 206, 210, 212-213, 226-227 (d'alej KELLER 1977).

8) PODLAHA, Antonín: Materiálie k slovníku umělců a uměleckých řemeslníků v Čechách, in: Památky archeologické, roč. 29, 1917, s. 272.

9) ČǏŽEK, Bohuslav: Nástrojové sbírky pražské konzervatoře, Hudební nástroje, roč. 18, 1981, č. 2, s. 58 (d'alej ČÍŽEK 1981); ČǏŽEK, Bohuslav: Nástrojové sbirky pražské konzervatoře, diplomová práca, Univerzita Karlova, Praha 1983, 2. diel (katalóg), s. 48-53. 
významný škótsky organológ Lyndsay G. Langwill,, ${ }^{10}$ na ktorého dielo nadviazal William Waterhouse v roku 1993. ${ }^{11} \mathrm{~V}$ rovnakom čase publikoval výsledky výskumu americký organológ, špecialista na drevené dychové nástroje Phillip T. Young. Aktualizoval v nich súpis zachovaných basetových rohov Franza Doleischa a špecifikoval záznamy o ich značkách, počte klapiek a priemere vŕtania. ${ }^{12} \mathrm{~V}$ súvislosti s Mozartovým pôsobením v Prahe uvádza zoznam zachovaných Doleischových basetových rohov Colin Lawson v práci z roku 1996, ktorý zostavil Nicholas Shackleton. ${ }^{13}$ O dekádu neskôr na ne nadviazala práca Thomasa Grassa a Dietricha Demusa, hodnotiaca progresivitu Doleischových basetových rohov najmä z pohladu zastúpenia diatonického a chromatického basetového registra. ${ }^{14}$ Klúčové postavenie Doleischa v stavbe a popularite basetových rohov v Čechách načrtáva Eric Hoeprich v monografii z roku 2008. ${ }^{15}$ Komplexnejší výskum amerického organológa Alberta R. Ricea z roku 2009 priniesol popri aktuálne známych biografických údajoch o Doleischovi I. a II. detailné konštrukčné a dizajnové špecifikácie jeho basetových rohov, ako napr. dekorované dotykové plochy as/es a $f / c^{2}$ klapiek, integrálny diel spájajúci tzv. koleno so stredným klapkovým dielom alebo špendlíkový typ čapov na klapky. ${ }^{16}$ Efektívnostou zvolených konštrukčných riešení Doleischových basetových rohov v kontexte dobovej nástrojárskej produkcie sa v jednom z tematických okruhov komparatívne zaoberá aj doktorská práca austrálskej bádatel'ky Melanie Piddockeovej z roku 2012. ${ }^{17}$

S odstupom viac ako 200 rokov môžeme na základe aktuálnych výsledkov skúmania súhlasit’ s tvrdením Dlabacza, že Franz Doleisch (tiež Dolejš, Doleysch, Doleyssý, Dolegschy, Dolegssy) patril k najvýznamnejším českým nástrojárom druhej polovice 18. storočia. Svoje výrobky datoval a označoval českým levom (od roku 1799 dvojhlavým orlom), menom a hviezdou. Najstarší zachovaný nástroj z roku 1781 rámcuje počiatky jeho nástrojárskej činnosti. ${ }^{18}$ Celý život pôsobil v Prahe. V rokoch 1792-1796 sa u neho vyučil pražský nástrojár

10) LANGWILL, G. Lyndesay: An Index of Musical Wind-Instrument Makers, $3^{\text {th }}$ ed., Lyndesay G. Langwill, Edinburgh 1972, s. 37 (d'alej LANGWILL 1972); LANGWILL, G. Lyndesay: An Index of Musical Wind-Instrument Makers, $6^{\text {th }}$ ed., Lyndesay G. Langwill, Edinburgh 1980, s. 41 (d'alej LANGWILL 1980).

11) WATERHOUSE, William: The New Langwill Index: $\mathcal{A}$ Dictionary of Musical Wind-Instrument Makers and Inventor, Tony Bingham, London 1993 (first edition), s. 92.

12) YOUNG, Phillip T.: 4900 Historical Woodwind Instruments: An Inventory of 200 Makers in International Collections, Tony Bingham, London 1993, s. 65-66 (d'alej YOUNG 1993).

13) LAWSON, Colin: Mozart Clarinet Concerto, Cambridge University Press, Cambridge 1996, s. 84, 87 (d'alej LAWSON 1996).

14) Diatonický basetový register zahŕn a tóny $d$ a c, chromatický es, $d$, cis, c. GRASS, Thomas - DEMUS, Dietrich: Das Bassetthorn. Seine Entwicklung und seine Musik, Books on Demand GmbH, Norderstedt 2004 (2. vydanie), s. 255 (d'alej GRASS-DEMUS 2004).

15) HOEPRICH, Eric: The Clarinet. The Yale Musical Instrument Series, Yale University Press, New Haven and London, 2008, s. 241 (d'alej HOEPRICH 2008).

16) RICE 2009, op. cit. v pozn. 3, s. 157-158.

17) PIDDOCKE 2012, op. cit. v pozn. 4, s. 177-178. Taktiež v českej doktorskej práci klarinetistu a basklarinetistu Lukáša Daňhela z roku 2015 je stručne zmienený basetový roh Franza Doleischa. DAŇHEL, Lukáš: Basetový roh - historický vývoj a dnešní použití, výberový rad doktorských prác, Janáčkova akademie múzických umění v Brně, Ediční středisko JAMU, Brno 2015, s. 33.

18) Týmto nástrojom je 4-klapkový hoboj z roku 1781, uložený v zbierke NM-ČMH pod inv. č. E 324. 
Josef Hallas (1779-1844). ${ }^{19}$ Medzi jeho učňov zrejme patril aj známy karlovarský nástrojár Franz Strobach (1769-1812). Na sklonku svojho života býval v Starom Meste v dome č. 692. Zomrel 9. júna 1805 vo veku 56 rokov. ${ }^{20}$ Po jeho smrti prevzal dielňu syn Franz Doleisch II. (1774-1810), ktorý zdielal rovnakú firemnú značku a zachoval aj prax datovania nástrojov. Keller uvádza, že Doleisch II. v rokoch 1807-1810 viedol pražský cech husliarov a výrobcov dychových nástrojov. Z rovnakého zdroja vieme, že v rokoch 1811-1812 po synovej smrti viedla firmu vdova po Doleischovi I. Anna Doleischová. ${ }^{21}$

\section{Zachované basetové rohy}

Doleischove hoboje, klarinety, basetové rohy a fagoty vykazujú vysokú kvalitu remeselného spracovania a umeleckej funkcionality (hracích vlastností). Dokazuje to vyše dvadsat zachovaných nástrojov v európskych a amerických nástrojových zbierkach. Z nich viac ako polovicu tvoria basetové rohy. $\mathrm{V}$ pomere $\mathrm{k}$ trom hobojom, štyrom klarinetom a dvom fagotom je štrnást' zachovaných basetových rohov reprezentatívnou vzorkou nástrojov, z ktorých sa dajú extrahovat’ konštrukčné a dizajnové štandardy. Na základe ich datovania (1790-1803) predpokladáme, že všetky postavil Franz Doleisch I.

\section{Súhrnný prehl'ad zachovaných basetových rohov Franza Doleischa}

(v sledujúcom zozname uvádzame popisky k jednotlivým nástrojom a všetky dostupné konštrukčné a dizajnové informácie)

\begin{tabular}{|c|c|c|c|c|c|c|}
\hline & Ročenie & Lad. & Lokalita, zbierka, inv. č. & Klapky & Vít. & Firemná značka \\
\hline 1 & 1790 & In $\mathrm{F}$ & Praha: NM-ČMHE 3008 & $8(c)$ & 13,6 & $\begin{array}{l}\text { Český lev / DOLEISCH / PRAG / } 1790 \\
\text { /** }\end{array}$ \\
\hline 2 & 1791 & $\operatorname{In} \mathrm{F}$ & Praha: NM-ČMHE 467 & $8(d, c)$ & $13,8-14,4$ & Český lev / DOLEISCH / PRAG / 1791 / * \\
\hline 3 & c. 1792 & $\operatorname{In} \mathrm{F}$ & Halle: Händel-Haus MS-406 & $7(c)$ & 13,8 & bez značky - prisúdený \\
\hline 4 & c. 1793 & $\operatorname{In} \mathrm{F}$ & Praha: NM-ČMHE 476 & $8(d, c)$ & 13,8 & bez značky-prisúdený \\
\hline 5 & 1793 & In $\mathrm{F}$ & $\begin{array}{l}\text { Praha: NM-ČMHE } 464 \\
\text { odpísaný zo zbierky }\end{array}$ & $8(d, c)$ & & Český lev / DOLEISCH / PRAG / 1793 / * \\
\hline 6 & 1793 & $\operatorname{In} \mathrm{F}$ & USA, NMM Vermillion 3541 & $8(d, c)$ & 13,0 & Český lev / DOLEISCH / PRAG / 1793 / * \\
\hline 7 & 1796 & In $\mathrm{F}$ & Praha: NM-ČMHE 466 & $9(e s, d, c)$ & $13,2-13,3$ & Český lev / DOLEISCH / PRAG / 1796 /* \\
\hline 8 & 1797 & $\operatorname{In} \mathrm{F}$ & Brusel: MIM 938 & $9(e s, d, c)$ & 13,8 & $\begin{array}{l}\text { Český lev / DOLEISCH / PRAG / } 1797 \text { / } \\
\star * * / 3\end{array}$ \\
\hline 9 & 1798 & In $\mathrm{F}$ & Praha: PK M I/43 & $10(c)$ & $13,1-13,8$ & $\begin{array}{l}\text { Českýlev / DOLEISCH / PRAG / } 1798 \\
\text { /** }\end{array}$ \\
\hline 10 & 1798 & $\operatorname{In} \mathrm{F}$ & Praha: PK M I/44 & $6(c)$ & 13,7 & Český lev / DOLEISCH / PRAG / 1798 / * \\
\hline 11 & 1798 & In $\mathrm{F}$ & Praha: PK M I/42 & $\begin{array}{c}12(e s, \\
d, c)\end{array}$ & $13,8-14,4$ & 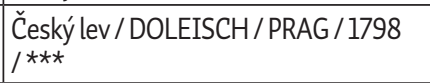 \\
\hline
\end{tabular}

19) KURFÜRST, Pavel: Brněnští hudební nástrojaři 14.- 19. století (Brünner Instrumentenbauer des 14.-19. Jahrhunderts), Moravské muzeum, Brno 1980, s. 67.

20) KELLER 1977, op. cit. v pozn. 7, s. 213. Z týchto údajov odhadujeme, že sa narodil v roku 1749.

21) Ibid. 


\begin{tabular}{|c|c|c|c|c|c|c|}
\hline & Ročenie & Lad. & Lokalita, zbierka, inv. č. & Klapky & Vít. & Firemná značka \\
\hline 12 & 1800 & $\operatorname{In} \mathrm{F}$ & USA: Aurand-CM Michigan & $13(d, c)$ & & $\begin{array}{l}\text { Dvojhlavý orol / DOLEISCH / PRAG / } \\
1800 \text { /*** }\end{array}$ \\
\hline 13 & 1803 & $\operatorname{In} \mathrm{F}$ & Londýn: RCM 90 & $9(e s, d, c)$ & 13,2 & $\begin{array}{l}\text { Dvojhlavý orol / DOLEISCH / PRAG / } \\
1803 \text { /***/F }\end{array}$ \\
\hline 14 & 1803 & $\operatorname{In} \mathrm{F}$ & Praha: MMP H 189529/001 & $6(d, c)$ & & $\begin{array}{l}\text { Dvojhlavý orol / DOLEISCH / PRAG / } \\
1803 / * \star / F\end{array}$ \\
\hline
\end{tabular}

\section{Morfológia a dizajn}

Franz Doleisch staval tzv. angulárny typ basetového rohu s viacnásobným lomením korpusu. Jeho charakteristickou črtou bolo mierne zakrivenie súdku (samostatný diel pod náustkom) cca v $155^{\circ}$ uhle. Najstarší datovaný basetový roh z roku 1790 (NM-ČMH, inv. č. E 3008) s pôvodným rovným súdkom však naznačuje, že Doleisch začal lomit’ súdok až počnúc rokom $1791 .^{22}$ Tento morfologický prvok zrejme prevzal z basetových rohov dráždanských stavitelov Augustina Grensera (1720-1807) a Jakoba Grundmanna (1727-1800). ${ }^{23}$ Vplyv týchto starších a skúsenejších kolegov, ktorí patrili k nemeckej nástrojárskej elite a pôsobili v ned’alekých Drážd’anoch, vidíme aj v prevzatí praxe datovania nástrojov a koncepcii užšieho „klarinetového“ vŕtania.

Druhé lomenie Doleischovho basetového rohu sa nachádza v polovici korpusu približne v $117^{\circ}$ uhle. Zabezpečuje ho tzv. koleno, ktoré je integrálne prepojené so stredným klapkovým dielom (s tónovými otvormi pre pravú ruku). Ich spojením sa odlíšil od väčšiny svojich kolegov, ktorí z dôvodu jednoduchšej výroby stavali koleno ako separátny diel. Výhodou integrálneho dielu bola väčšia kompaktnost̉ nástroja bez obmedzenia pozície basetového rohu pri hre vpravo od hráčovho tela, alebo v centrálnej polohe medzi hráčovými nohami. Renomovaný nemecký klarinetista Johann Heinrich Backofen v roku 1803 v tejto súvislosti uviedol, že basetový roh s umiestnením vpravo (od tela hráča) používajú klarinetisti, ktorí hrajú s plátkom oproti dolnej pere, zatial čo centrálnu pozíciu využívajú hráči s plátkom otočeným oproti hornej pere. ${ }^{24}$

Najostrejšie je Doleischov basetový roh lomený v tzv. knihe - drevenom púzdre, v ktorom je vnútorný tubus dvakrát meandrovo zavinutý v $180^{\circ}$ uhle predtým, než vyústi do mosadznej ozvučnice. ${ }^{25}$ Touto črtou sa basetový roh už v prvopočiatkoch svojej existencie odlišoval

22) Basetový roh z roku 1803 (RCM, inv. č. 90) má tiež rovný súdok, ale ten nie je pôvodný.

23) Najstarší basetový roh Carla Augustina juniora Grensera pochádza z roku 1784 a nachádza sa v zbierke Scenkonstmuseet v Stockholme, inv. č. M553 (dostupné z https://mimo-international.com/MIMO/doc/IFD/ OAI_SMS_MM_POST_553) [cit. 8. 4. 2021]. Najstarší basetový roh Jakoba Grundmanna tiež z roku 1784 vlastní Rudolf Tutz mladší v Innsbrucku. Pozri SCHLADER, Ernst - TUTZ, Rudolf: Das früheste bekannte Bassethorn von Jakob Friedrich Grundmann, in: Geschichte, Bauweise und Repertoire der Klarinetteninstrumente. Michaelsteiner Konferenzberichte, Band 77, eds. Monika Lustig - Boje E. Hans Schmuhl, Kloster Michaelstein - Musikakademie/Museum, Augsburg - Michaelstein 2008, s. 123-126.

24) BACKOFEN, Johann Heinrich: Anweisung zur Klarinette (Neue teoretisch-prachtische Klarinett Schule) nebst einer kurzen Abhandlung über das Bassett-Horn, Leipzig 1803, reprint: Moeck Verlag, Celle 1986, s. 37 (d'alej BACKOFEN 1803).

25) Kniha je názov pre púzdro, skrinku alebo krabičku, v ktorej sú vyvŕtané tri vzájomne prepojené kanály tubusu. Jeho dvojitým zavinutím v knihe sa skracuje exteriérna dľžka basetového rohu tak, aby ozvučnica pri 


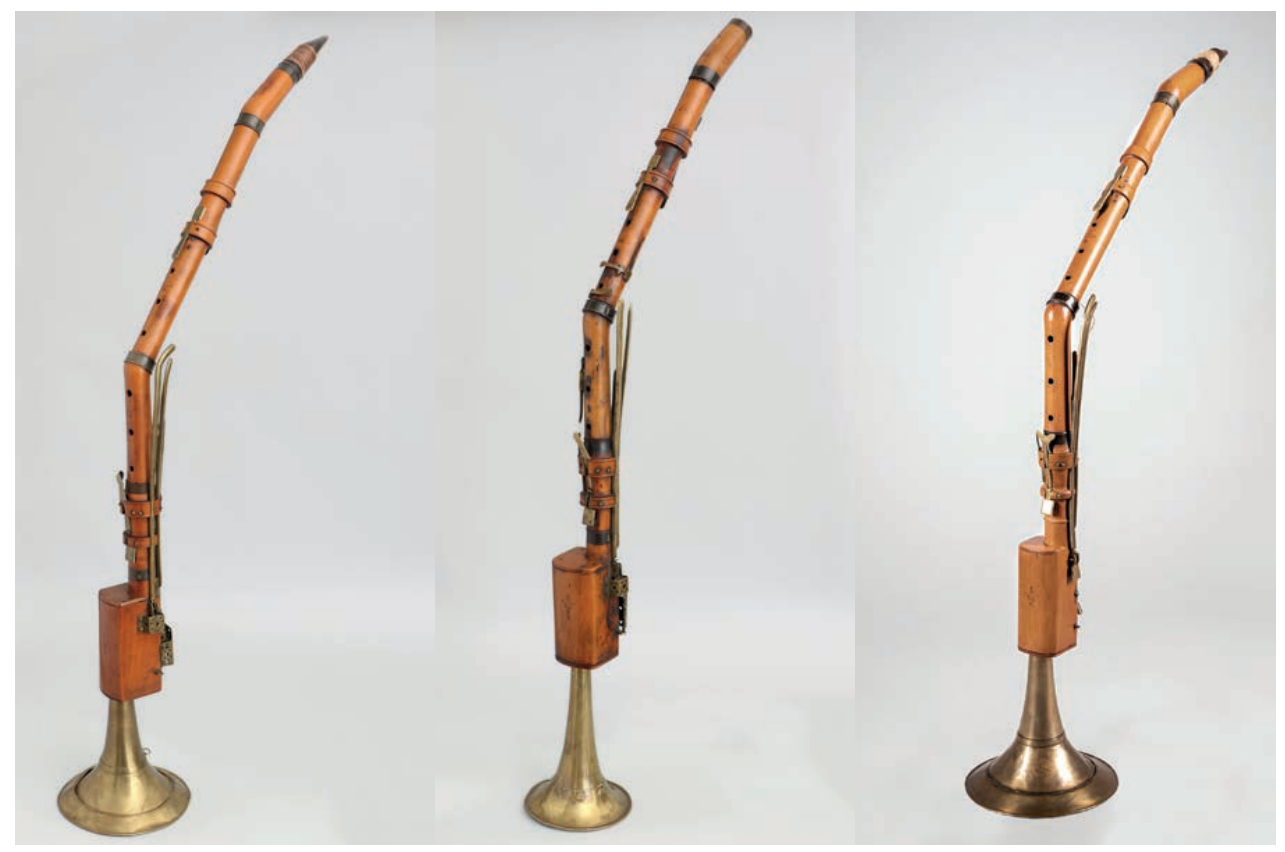

\section{Basetové rohy: celkový záber na sériu nástrojov}

NM-ČMH E 466, PK M I/ 42, NM-ČMH E 467 (z l'ava do prava)

(๑) Jan Kř́ženecký

od loveckého hoboja, s ktorým zdielal pôvodný oblúkový tvar. Pomocou zavinutia v knihe sa dostatočne rozšíril spodný „basetový“ register bez predĺženia exteriérnej dĺžky nástroja, čím sa zabezpečila akusticky vhodná pozícia ozvučnice nad zemou na efektívne šírenie zvuku do priestoru pri hre v sede. ${ }^{26}$ Zatial čo na viedenských basetových rohoch sú tri kanály radené za sebou (kniha je plochá), Doleisch ich umiestňuje do trojuholníka, podobne ako nemeckí výrobcovia. Druhý kanál je umiestnený vpravo a tretí kanál vystupuje dopredu od korpusu, čím drevené púzdro získava skôr tvar krabičky. Na jej plochej zadnej strane sú inštalované klapky basetového registra, ovládané palcom pravej ruky.

Špecifickým dizajnovým prvkom Doleischových basetových rohov (aj klarinetov) sú dekorované kraje drevených prstencov. ${ }^{27} \mathrm{Na}$ vzorke štrnástich basetových rohov môžeme vidiet', že Doleisch tento dekor prstencov začal používat približne od roku 1793. Nástroje uložené v NM-ČMH so starším datovaním z roku 1790 (inv. č. E 3008), 1791 (inv. č. E 467) a 1793 (inv. č. E 464) ho nemajú. Počnúc nástrojom v NMM Vermillion, vyrobeným

hre v sede mohla zostat'v správnej akustickej pozícii nad zemou a zároveň zachováva potrebnú dížku tubusu pre najspodnejšie tóny basetového rohu. Krabička s tromi kanálmi, radenými za sebou, svojim tvarom pripomínala knihu. Z tejto morfologickej asociácie pochádza názov kniha, ktorý sa ujal v súčasnej odbornej terminológii v anglickom jazyku. V nemeckom jazyku sa používa historický termín „Kasten“.

26) Termín basetový ako diminúcia slova basový označuje najhlbší register nástroja a v jeho názve indikuje schopnost' hrat' $v$ basovom registri, nie však tak hlboko ako fagot, kontrabas a pod.

27) $O$ čosi neskôr ich používal aj Franz Strobach, ktorý sa zrejme učil vyrábat' basetové rohy v dielni Franza Doleischa. Pozri: ŠEBESTA 2009, op. cit. v pozn. 4. 
v roku 1793, sú všetky d’alšie exempláre dekorované. Pomocou tejto dizajnovej inovácie vieme presnejšie datovat’ vznik dvoch neznačkovaných basetových rohov, ktoré sú na základe konštrukčných a dizajnových charakteristík Doleischovi prisúdené. Prvým je basetový roh v NM-ČMH s inv. č. E 476. Ide o nástroj bez dekorovaných prstencov, ktorý má pomerne archaický dizajn as/es² klapky. Preto predpokladáme, že bol postavený pred rokom 1793. Druhým basetovým rohom bez značky je nástroj v zbierke Händel-Haus v nemeckom Halle (d’alej Händel-Haus), ktorý má už drevené prstence dekorované a preto bol zrejme postavený v roku 1793 alebo neskôr. ${ }^{28}$

Ďalším premenlivým prvkom v konštrukcii Doleischových basetových rohoch je integrálne prepojenie spodného klapkového dielu (stock) s knihou, ktoré sa objavuje na starších nástrojoch, zatial čo na mladších exemplároch (1796-1803) sú zmienené diely oddelené. Výnimkou je iba najstarší basetový roh z roku 1790 (NM-ČMH, inv. č. E 3008), ktorý ich má oddelené, napriek staršiemu roku výroby. Určujúcim pre spresnenie datovania Doleischových basetových rohov sú aj mosadzné ochranné krytky na spodných klapkách. Tie chýbajú iba na najstarších datovaných nástrojoch z rokov 1790-1793, zatial čo basetové rohy s neskorším datovaním z rokov 1796-1803 ich majú.

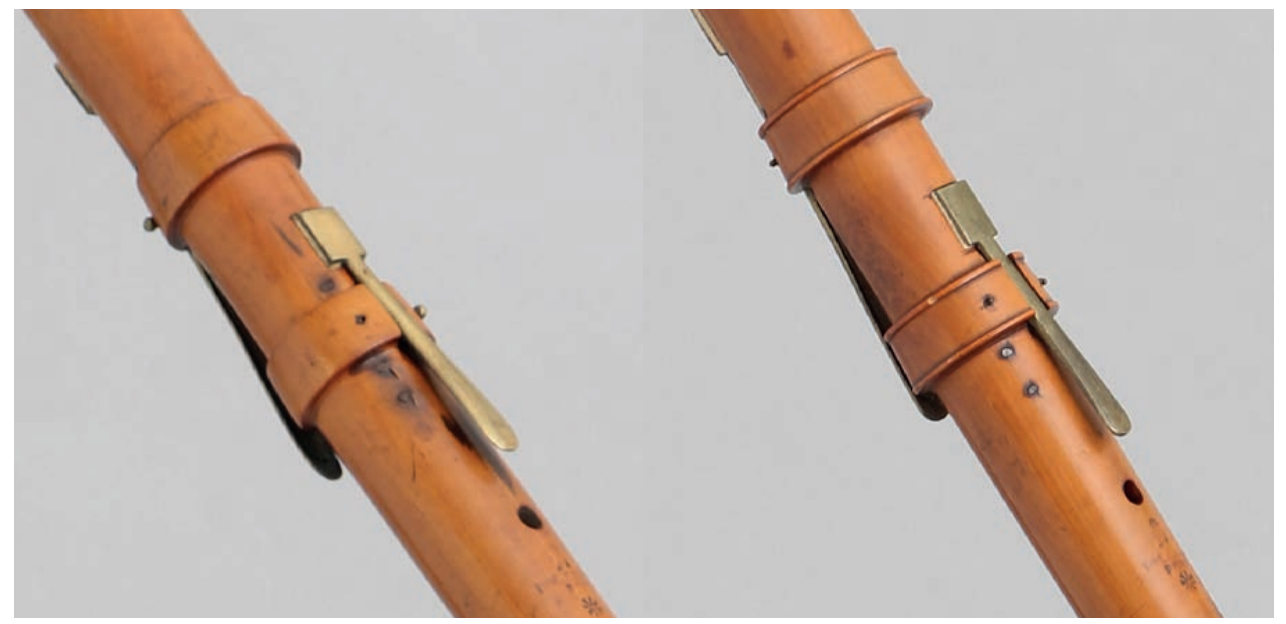

Záber na vrchnú polovicu nástrojov bez dekoru a s dekorom drevených prstencov NM-ČMH E 467, NM-ČMH E 466 (z l'ava do prava) (c) Jan Kř́žzenecký

\section{Priemer vŕtania}

Dôležitým konštrukčným aspektom koncepcie Doleischových basetových rohov je šírka vnútorného vŕtania tubusu. Viedenskí nástrojári, napr. Theodor Lotz či Raymund Griesbacher, stavali svoje basetové rohy s výrazne väčším vŕtaním ako klarinety (basetové

28)HEYDE, Herbert: KatalogzudenSammlungen des Händel-Hauses in Halle. 7. Teil: Musikinstrumentensammlung: Blasinstrumente, Orgeln, Harmoniums, Händel-Haus, Halle 1980, s. 224-225 (d'alej HEYDE 1980). 
rohy 15,4-15,9 mm, klarinety cca 14,5-14,9 mm). ${ }^{29}$ Reagovali tým na fakt, že basetový roh mal výrazne dlhší tubus ako klarinet. Doleisch si pod vplyvom nemeckej nástrojárskej praxe zvolil pri stavbe basetového rohu rovnaký priemer vŕtania ako na klarinetoch (cca 13,5-14,2 mm). Výsledkom bol farebne koncentrovanejší tón, ale aj pomerne stabilná intonácia labilnejších tónov produkovaných tzv. vidličkovými hmatmi $b, f^{2}, e s^{1}, b^{2}$, či intonácia a znenie tónu $f$. Nevýhodou bol dynamicky subtílnejší zvuk, vhodný na komornú hru v menších priestoroch. Do orchestra sa lepšie hodili viedenské basetové rohy so širším vŕtaním, ktoré produkovali väčší a dynamicky silnejší tón. Páčili sa aj klarinetistovi Johannovi H. Backofenovi, ktorý ich považoval za najlepšie. ${ }^{30}$ Naproti tomu sa zdá, že „klarinetové“ vŕtanie na Doleischových basetových rohoch bolo až príliš úzke. Negatívom bola menšia farebná diferencovanost' v porovnaní s klarinetovým tónom a tiež nižšia zvuková prieraznost’ najspodnejších „basetových“ tónov.

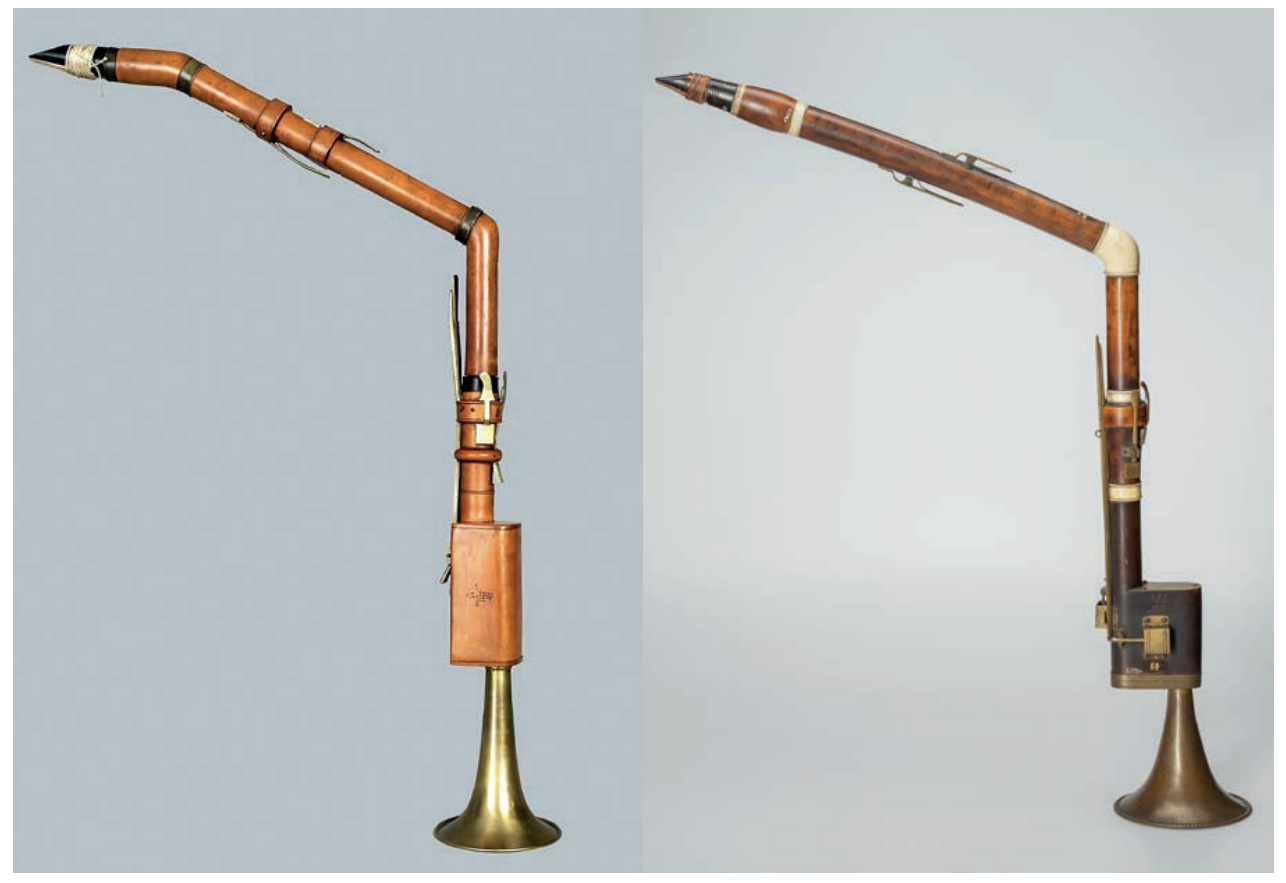

Ukážka Doleischovho modelu a basetového rohu Theodora Lotze

NMM Vermillion 3541, NM-ČMH E 1365 (z l'ava do prava)

(c) NMM Vermillion, Creative Dreamers Production s.r.o.

\section{Počet a dizajn klapiek}

Doleisch staval basetové rohy s konštantným počtom klapiek. Inštalované sú v drevených prstencoch a majú štvorcový tvar. Ich množstvo záviselo od počtu basetových klapiek, zostávajúca konfigurácia sa nemenila. Celkový počet pôvodných klapiek sa pohyboval od

29) HOEPRICH, Eric: $A$ Trio of Basset Horns by Theodor Lotz, The Galpin Society Journal, 1997, č. 50, s. 228-236. 30) „Die besten mir bekannten Bassethörner sind die Wiener, ...". BACKOFEN 1803, op. cit. v pozn. 24, s. 36. 
sedem do devät. Pôvodne sedemklapkové modely majú iba jednu basetovú klapku (tón $c$ ). Tento typ reprezentujú basetové rohy z rokov 1790 (NM-ČMH, inv. č. E 3008), cca 1792 (Händel-Haus, inv. č. MS-406) a tiež 1798 (PK, inv. č. M I/42, M I/43). Osemklapkové modely zahŕňajú dve basetové klapky pre tóny $d$ a $c$. Toto vývojové štádium reprezentuje šest’ basetových rohov: tri z NM-ČMH (inv. č. E 467, E 464, E 476), dva z dvoch amerických zbierok - NMM Vermillion (inv. č. 3541) a Aurand CM Michigan (bez inv. č.) a jeden z MMP (inv. č. H 189 529/001). Najprogresívnejšie basetové rohy s tromi basetovými klapkami es, $d, c$ nájdeme na štyroch nástrojoch: v bruselskej zbierke (MIM, inv. č. MIM 938), PK (inv. č. M I/42), NM-ČMH (inv. Č. E 466) a RCM (inv. č. 90). Podla N. Shackletona sú najstaršími basetovými rohmi s basetovou es klapkou. ${ }^{31}$ Dodatočné klapky, rozširujúce počet na 10 až 13 , sú osadené v mosadzných sedlách a s najväčšou pravdepodobnostou nie sú originálne. S výlučne pôvodnými klapkami tvoria Doleischovu sadu zachovaných basetových rohov štyri sedemklapkové modely s čiastočne diatonickým basetovým registrom, šest̉ osemklapkových modelov s kompletným diatonickým basetovým registrom a štyri devätklapkové exempláre s polochromatickým basetovým registrom.

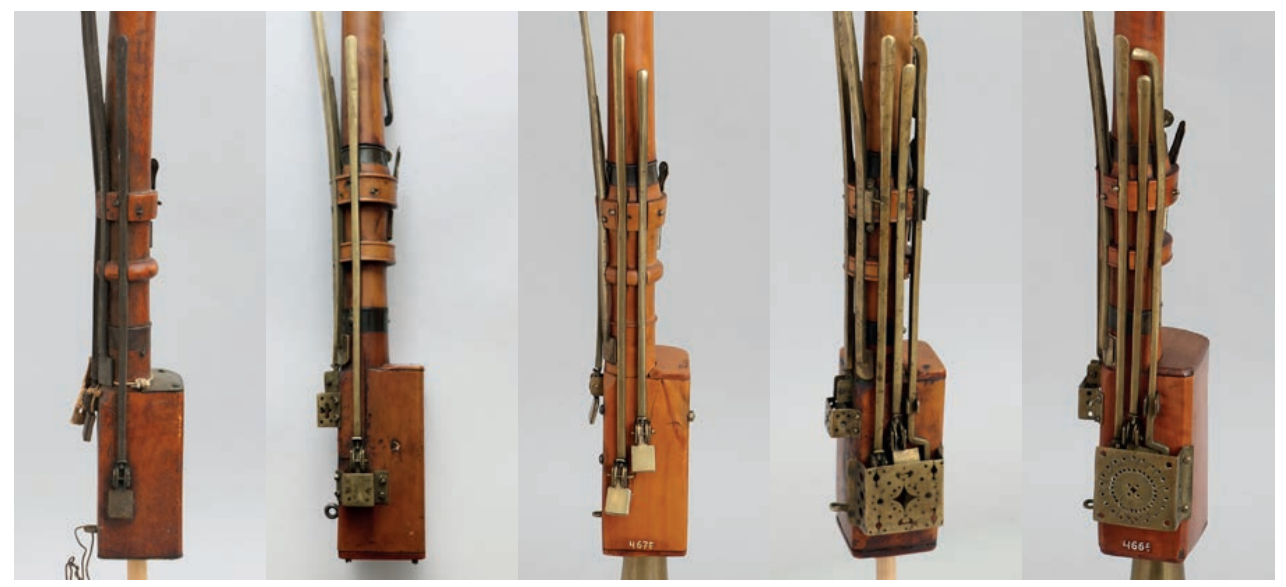

Ukážka série basetových klapiek: modelu s jednou (NM-ČMH E 3008, PK M I/43), dvoma (NM-ČMH E 467) a tromi basetovými klapkami (PK M I/ 42, NM-ČMH E 466) (c) Jan Kř́iženecký

V klapkovom dizajne Doleischových basetových rohov nachádzame aj výrazne odlišnú dĺžku pák dvoch otvorených basetových klapiek (tóny $d, c$ ) v hornej oblasti dotykových plôch, ktorá pôsobí neergonomicky, pokial je nástroj umiestnený v strede medzi hráčovými nohami. Naopak, otočením spodnej polovice nástroja vpravo od hráčovho tela (pravej nohy) sa obe zmienené klapky stávajú pohodlne ovládatelné. Tejto pozícii zodpovedá aj umiestnenie mosadzného oka na šnúru na lavej strane knihy, pomocou ktorého sa nástroj fixoval

31) SHACKLETON, Nicholas: The Earliest Basset Horns, The Galpin Society Journal, č. 40, 1987, s. 12 (d'alej SHACKLETON 1987). Výskyt basetovej es klapky je klúčcvý z pohl'adu chromatizácie basetového registra a jeho plnohodnotného umeleckého využitia. Pôvodne diatonický basetový register s tónmi $d$ a $c$ výrazne limitoval hudobné využitie basetového rohu v rôznych tóninách. 
počas hry v sede. Je zrejmé, že Doleisch nastavil ergonómiu ovládacích prvkov tak, aby horná polovica nástroja išla rovnobežne s telom hráča a v kolene sa spodná čast’ basetového rohu otočila vpravo od jeho tela. Odlišný prístup vidíme na basetovom rohu v zbierke RCM, ktorý je dizajnovaný na hru s centrálnym umiestnením. ${ }^{32}$ Dotykové časti pák všetkých troch basetových klapiek sú rovnako dlhé a oko na šnúru je umiestnené v strede spodnej časti knihy tak, aby všetky prvky vyhovovali ergonómii hry s nástrojom v centrálnej pozícii.

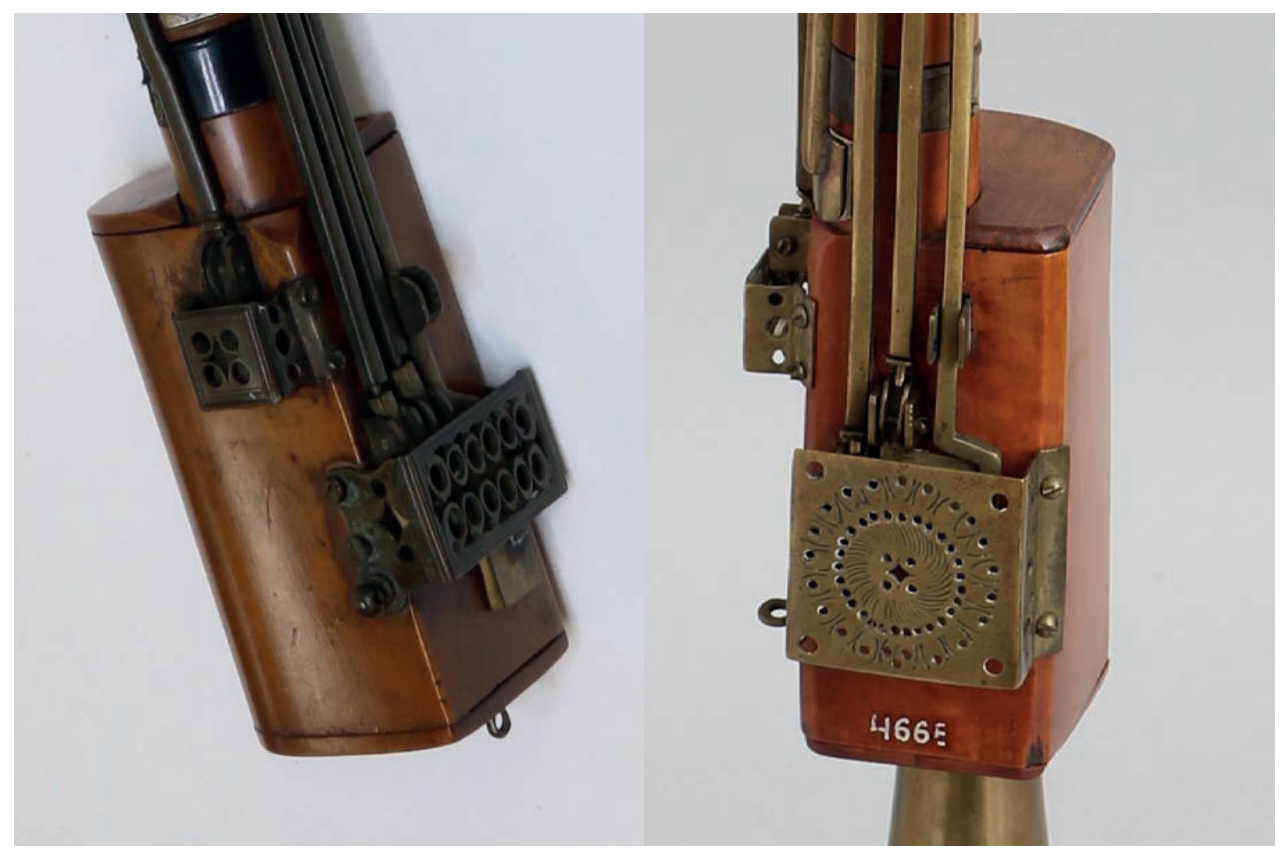

Detailný pohl'ad na rôzne umiestnenie oka na zavesenie basetového rohu RCM 90, NM-ČMH E 466

(c) RCM, Jan Kř́ženecký

Vzhladom na dátum výroby je prekvapivé, že až štyri Doleischove basetové rohy sú vybavené len jednou basetovou klapkou. Ich produkcia po roku 1790 pôsobí vývojovo anachronicky, pretože basetové rohy bez basetovej $d$ klapky sa v tomto čase bežne nestavali. V prípade basetových rohov z roku 1798 zo zbierky PK môže byt’ dôvod len jednej basetovej klapky iný. ${ }^{33} \mathrm{~V}$ ich prípade sa zrejme počítalo s tým, že v rámci sady troch basetových rohov nebudú dva z nich využívané na hru spodného partu. Na tento účel slúžil výlučne basetový

32) Na basetovom rohu v zbierke MMP sa nachádzajú dve oká: jedno na hru s nástrojom vpravo od hráča a druhé na jeho centrálne umiestnenie.

33) Podl'a špecifického fundamentálneho ladenia a značky (rovnaký rok výroby) usudzujeme, že boli postavené ako sada troch nástrojov. Okrem mena, lokality a ročenia sú tieto nástroje označené číslicami 1, 2, 3. S týmto číselným označením korešponduje počet hviezd pod značkou. Očíslovanie jednotlivých dielov malo slúžit k tomu, aby sa diely dvoch či troch nástrojov (vyrobené ako súčast' jednej objednávky) nepomiešali a tým nezmenili ich hracie vlastnosti. Prax číslovania basetových rohov nachádzame aj u iných nástrojárov, napr. Franza Strobacha a Johanna Theodora Lotza. 


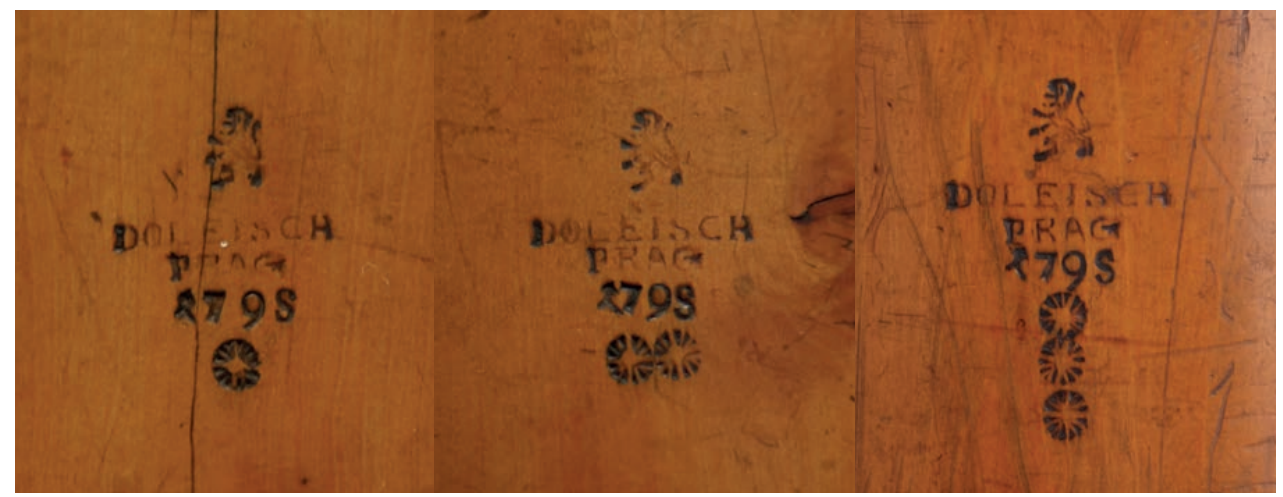

Detail na tri značky Doleischových basetových rohov

zo zbierky Pražského konzervatória, vyrobených v roku 1798 ako sada PK M I/44, PK M I/43, PK M I/42

(c) Jan Kř́ženecký

roh s inv. č. M I/42 s tromi basetovými klapkami es, $d$, $c$, ktorý v triu plnil funkciu najhlbšieho hlasu. Ostatné dva basetové rohy hrali vo vyšších rozsahových polohách, v ktorých basetové klapky nepotrebovali. Preto podla nás majú len jednu basetovú $c$ klapku. Absenciou $d$ a es basetovej klapky sa výrazne skrátil čas ich výroby a podstatne znížila aj predajná cena. ${ }^{34}$ Basetové rohy boli vo všeobecnosti velmi drahé a ich objednávatel' určite ocenil možnost’ zníženia celkovej ceny zredukovaním počtu basetových klapiek na dvoch $\mathrm{z}$ troch nástrojov. $\mathrm{Na}$ d’alších basetových rohoch $\mathrm{s}$ jednou basetovou klapkou z roku 1790 (NM-ČMH, inv. č. E 3008) a z cca 1792 (Händel-Haus, inv. č. MS-406) sú dôvody absencie $d$ basetovej klapky neznáme. Isté je, že výrazne obmedzuje ich umelecké využitie v spodnom registri.

Na určitú previazanosť českej a nemeckej nástrojárskej oblasti poukazuje „hobojové“ umiestnenie as $/ e s^{2}$ a $f / c^{2}$ klapky. V porovnaní s dobovými klarinetmi sú osadené opačne, čo zásadne komplikuje hru na oboch nástrojoch, najmä ich rýchle striedanie v opere apod. Túto „anachronickost" nachádzame aj na väčšine dobových basetových rohoch nemeckej proveniencie. Viedenskí výrobcovia,

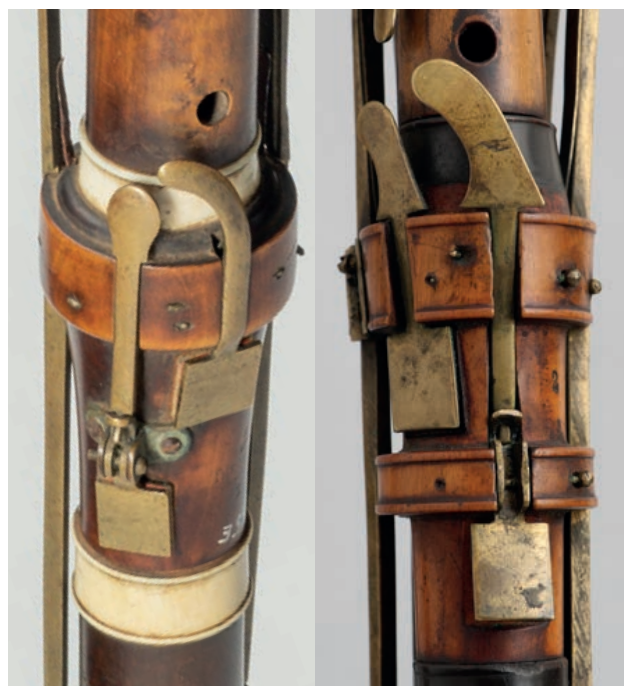

Detailný pohl'ad na opačné umiestnenie klapky as $/ \mathrm{es}^{2}$ a $f / \mathrm{c}^{2}$ na Lotzovom a Doleischovom basetovom rohu

NM-ČMH E 1365, PK M I/42

(c) Creative Dreamers Production s.r.o., Jan Kř́ženecký

34) ŠEBESTA, Róbert: Basetové rohy prešporskej firmy Schöllnast (Basset horns by the Schöllnasts in Pressburg), Vysoká škola múzických umení, Bratislava 2019, s. 57. 
napr. Johann Theodor Lotz, Raymund Griesbacher či Johann Baptist Merklein, stavali svoje basetové rohy s identickou pozíciou $a s / e s^{2}$ a $f / c^{2}$ klapiek ako na klarinetoch, čo výrazne ulahčovalo striedanie oboch nástrojov.

Na dotykovej časti as/es² klapky je podla autorov štúdie najzretel’nejšie vidiet’ vývoj v dizajne Doleischových basetových rohov. Tzv. motýlový tvar sa vyskytuje na najstarších basetových rohoch z roku 1790 (NM-ČMH, inv. č. E 3008) a 1791 (NM-ČMH, inv. č. E 467). Len o čosi modernejší dizajn má dotyková čast’ as/es² klapky na basetovom rohu z roku cca 1793 (NM-ČMH, inv. č. E 476). Naopak najmodernejší je v tomto ohlade najmladší Doleischov basetový roh v zbierke RCM, na ktorom sú dotykové časti as/es² klapky dizajnovo zjednotené s ostatnými klapkami.

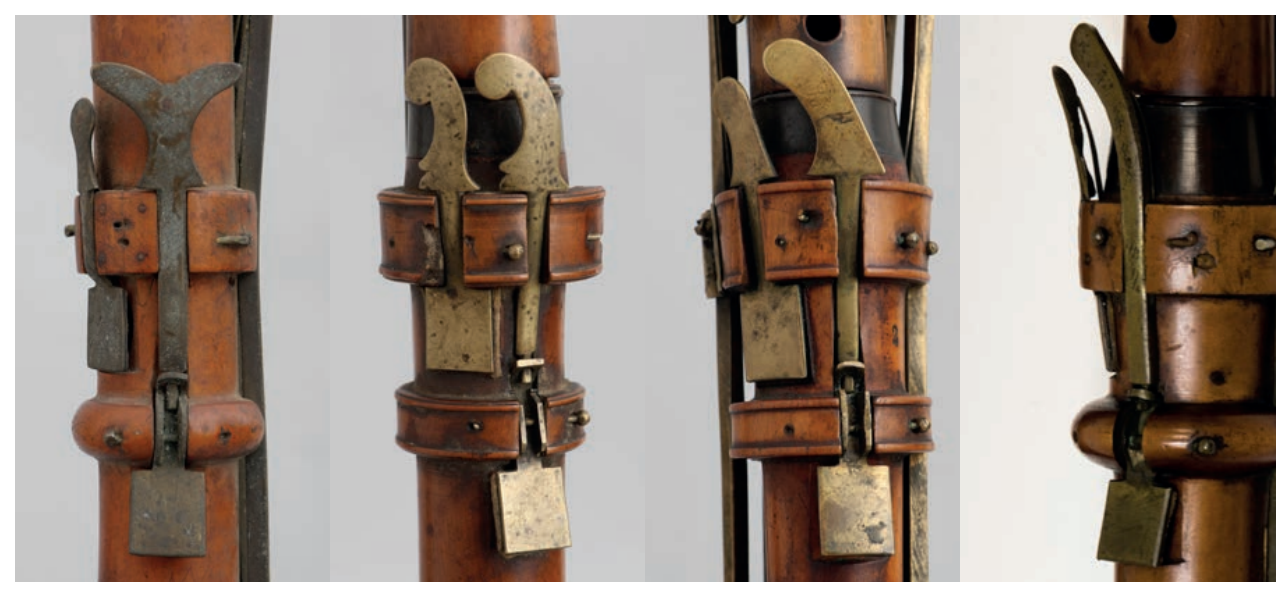

Basetové rohy z rokov 1790 (NM-ČMH E 3008), cca 1792-1793 (NM-ČMH E 476), 1798 (PK M I/42), 1803 (RCM 90) (z l'ava do prava)

๑) Jan Kříženecký, RCM

\section{Firemná značka}

Doleischova firemná značka je zdrojom dôležitých informácií. Neocenitelným je najmä ročenie značkovaných nástrojov. Vdaka nemu dokážeme presne určit chronológiu konštrukčných a dizajnových inovácií. Konštantami Doleischovej značky sú hviezda, meno výrobcu, lokalita a český lev. ${ }^{35}$ Jej premenlivým prvkom označenie jednotlivých dielov v prípade dodania viacerých identických nástrojov jednému klientovi. $\mathrm{V}$ takom prípade sú nástroje na každom dieli

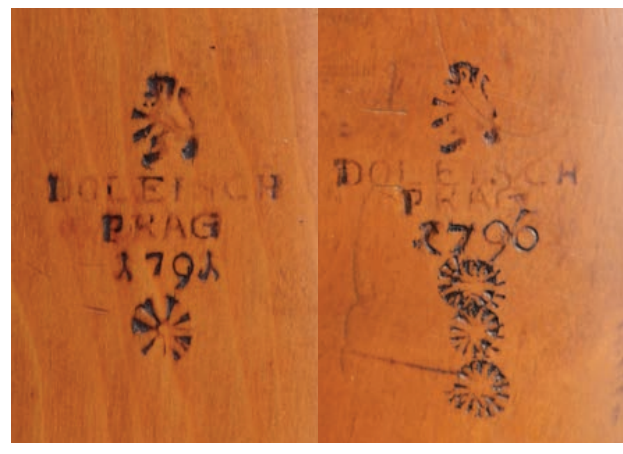

Detail Doleischových značiek s rôznym ročením NM-ČMH E 467, NM-ČMH E 466

(c) Jan Kř́iženecký

35) Na basetových rohoch v Aurand CM Michigan, RCM a MMP má značka miesto českého leva znak dvojhlavého orla. 
označené rovnakou číslicou alebo príslušným počtom hviezd (jednou, dvomi či tromi), aby sa zamedzilo ich pomiešaniu. Č́slovanie dielov nachádzame predovšetkým na basetových rohoch, ktoré sa bežne dodávali v sérii dvoch či troch kusov. Rovnakú prax využíval aj Franz Strobach či Theodor Lotz. ${ }^{36}$

\section{Záver}

Z pohladu výroby drevených dychových nástrojov 18. storočia je stavba basetového rohu bezkonkurenčne najzložitejším procesom, na ktorý si trúfli len tí najlepší nástrojári. Jeho náročnost’ sa priamo úmerne zrkadlila v dĺžke výroby, ktorá násobne presahovala produkciu ostatných dobových drevených dychových nástrojov. Platí to predovšetkým pri modeloch s chromatickým basetovým registrom, ktoré ako jeden z prvých staval práve Franz Doleisch I. Jeho koncepcia basetového rohu s úzkym vŕtaním predstavuje konštrukčnú aj zvukovú alternatívu k viedenskému modelu. Štrnást̉ zachovaných basetových rohov postavených v rokoch 1790-1803 dokazuje, že sa ich stavbou a vývojom zaoberal dlhodobo. ${ }^{37}$ Niet pochýb, že z pohladu kvality remeselného spracovania sa radia k najlepším v 18. storočí. Aktuálny stav bádania však túto skutočnost̉ nereflektuje. Doleischovou nástrojárskou produkciou sa komplexne dosial nik nezaoberal. Napriek niekol’kým vyššie uvedeným bádatel’ským sondám nemá Franz Doleisch heslo ani v najnovšom vydaní The Grove Dictionary of Musical Instruments (2014). ${ }^{38}$ To je tiež dôvod, prečo vznikla táto štúdia. Jej cielom je nielen zhromaždenie doteraz publikovaných informácií o výrobcovi, ale predovšetkým prezentácia výsledkov prvej fázy výskumu, zameraného na Doleischove zachované basetové rohy v českých a svetových nástrojových zbierkach so špecifikáciou ich tvarovej charakteristiky. V d’alšej etape sa bude zameriavat na archívnu prácu, smerujúcu k objasneniu chýbajúcich biografických a profesných dát o Doleischovi, pričom výsledky tohto výskumu by mali prispiet’ k stavu bádania o d’alších výrobcoch drevených dychových nástrojov z prelomu 18. a 19. storočia $\mathrm{v}$ stredoeurópskom priestore. $\mathrm{V}$ neposlednom rade by sa mali doplnit informácie o d’alších Doleischových zachovaných basetových rohoch, respektíve dalších nástrojových druhoch. Výsledky čiastkového výskumu už v tejto fáze jednoznačne preukazujú, že Franz Doleisch I. sa právom radí k elitným európskym nástrojárom 2. polovice 18. storočia.

36) ŠEBESTA, Róbert: Strobach basset horn production in the light of new biographical discoveries, in: Geschichte, Bauweise und Repertoire der Klarinetteninstrumente. Michaelsteiner Konferenzberichte, Band 77, eds. Monika Lustig - Boje E. Hans Schmuhl, Kloster Michaelstein - Musikakademie/Museum, Augsburg Michaelstein 2008, s. 113-121.

37) Doleisch staval výlučne angulárny basetový roh s viacnásobným lomením a knihou. F. Strobach s výnimkou jedného nástroje vyrábal basetové rohy iba s jedným lomeným korpusom, bez knihy a s gul'ovým ozvučníkom.

38) The Grove Dictionary of Musical Instruments, ed. Laurence Libin, vol. 2, Oxford University Press, $2^{\text {nd }}$ edition, 2014. 


\section{Zoznam zachovaných nástrojov}

1.

\section{Basetový roh v F ladení, rok výroby 1790}

chýba náustok a ozvučnica

Značka: Český lev / DOLEISCH / PRAG / 1790 / * *

Lokalita a zbierka: NM-ČMH, inv. č. E 3008

Dizajn a materiál: angulárny model s knihou, diatonický basetový register, krušpánové drevo, rohovinové prstence, vŕtanie 13,6 mm

Klapky: 8 mosadzných klapiek štvorcového tvaru, 7 pôvodných klapiek $a^{1}, b^{l}$ (prefuková klapka), as $/ e s^{2}, f / c^{2}, f i s / c i s^{2}, e / h^{1}$, basetová $c, 1$ dodatočná klapka: $c i s^{1} / g i s^{2}$

Špecifiká: rovný súdok, oddelené koleno ( $117^{\circ}$ uhol), kovové krytky na knihe, as/es ${ }^{2}$ klapka má dotykovú čast’ v archaickom tvare motýla. Náustok zrejme nie je pôvodný (vŕtanie 14,5 mm).

2.

\section{Basetový roh v F ladení, rok výroby 1791}

kompletný

Značka: Český lev / DOLEISCH / PRAG / 1791 / *

Lokalita a zbierka: NM- ČMH, inv. č. E 467

Dizajn a materiál: angulárny model s knihou, zahnutý súdok ( $155^{\circ}$ uhol), integrálne koleno (117 ${ }^{\circ}$ uhol), diatonický basetový register, krušpánové drevo, rohovinové prstence, mosadzná ozvučnica kruhového tvaru, diatonický basetový register, vŕtanie 13,8-14,4 mm, celková dížka nástroja bez ozvučnice 985 mm

Klapky: 8 mosadzných klapiek štvorcového tvaru: $a^{1}, b^{1}, a s / e s^{2}, f / c^{2}, f i s / c i s^{2}, e / h^{1}$, basetová $d$, basetová $c$

Špecifiká: Spodný klapkový diel (stock) je integrálne prepojený s knihou. Tá je zvrchu a zospodu uzavretá drevenými krytmi. Basetové klapky bez ochranných krytiek, as/es² má dotykovú čast' klapky v archaickom tvare motýla.

Literatúra: Průvodce výstavou české hudebni nástroje minulosti v břevnovském klášteře sv. Markéty, Národní muzeum, Praha 1950, s. 33 (d’alej Průvodce); LANGWILL 1972, s. 37; CULKA, Zdeněk RUTOVÁ, Milada - ŠERÝCH, Jaroslav: Muzeum hudebních nástroju․ Katalog stálé expozice hudebních nástrojů hudebního oddělení Národního muzea v Praze, 2. vyd., Národní muzeum, Praha 1973, s. 39; LANGWILL 1980, s. 41; YOUNG 1993, s. 65; BRECHLIČUKOVÁ, Irena: Franz Strobach - „unbekannt" nejen v Karlových Varech. Hudebni nástrojářství a kultura v Čechách na prelomu 18. a 19. století, magisterská práce, Filozofická fakulta Masarykovy univerzity, Brno 2003, s. 10, 41, 43, 54 (dalej BRECHLIČUKOVÁ 2003); GRASS-DEMUS 2004, s. 254; PIDDOCKE 2012, s. 415-416.

\section{3.}

Basetový roh v F ladení, rok výroby cca. 1792

chýba náustok a ozvučnica

Značka: bez značky, prisúdený

Lokalita a zbierka: NM- ̌́MH, inv. č. E 476 
Dizajn a materiál: angulárny model s knihou, krušpánové drevo, rohovinové prstence, zahnutý súdok $\left(155^{\circ}\right)$, integrálne koleno $\left(117^{\circ}\right)$, diatonický basetový register, vŕtanie 13,8 mm, celková dĺžka nástroja bez ozvučnice $985 \mathrm{~mm}$

Klapky: 8 mosadzných klapiek štvorcového tvaru: $a^{1}, b^{1}$, as $/ e s^{2}, f / c^{2}, f i s / c i s^{2}, e / h^{1}$, basetová $d$, basetová $c$

Špecifiká: Nástroj má mosadzné kovanie na vrchnej a spodnej strane knihy. Všetky prstence sú dekorované. Integrálny spodný klapkový diel s knihou. Chýba fis/cis² a basetová c klapka, dotykové časti as/es ${ }^{2}$ a $f / c^{2}$ klapiek sú archaicky dizajnované.

Literatúra: SHACKLETON 1987, s. 17, podč. pozn. 12; RICE 2009, s. 157-158.

4.

\section{Basetový roh v F ladení, rok výroby cca 1793}

ozvučnica nie je pôvodná

Značka: bez značky a roku výroby, prisúdený

Lokalita a zbierka: Händel-Haus, inv. č. MS-406

Dizajn a materiál: angulárny model s knihou, zahnutý súdok $\left(155^{\circ}\right)$, integrálne koleno $\left(117^{\circ}\right)$, krušpánové drevo, rohovinové prstence, mosadzné klapky, nekompletný diatonický basetový register, celková dĺžka nástroja od súdku po koniec knihy $891 \mathrm{~mm}$, vŕtanie 13,8 mm Klapky: 7 mosadzných klapiek plochého štvorcového tvaru: $a^{1}, b^{1}, a s / e s^{2}, f / c^{2}, f i s / c i s^{2}, e / h^{1}$, basetová $c$

Špecifiká: Nástroj nemá ochranné krytky na najspodnejšie klapky. Prstence sú dekorované. Nástroj má len jednu basetovú $c$ klapku.

Literatúra: HEYDE 1980, s. 224-225; RICE 2009, s. 136.

5.

\section{Basetový roh v F ladení, rok výroby 1793}

kompletný

Značka: * Český lev / DOLEISCH / PRAG / 1793 / *

Lokalita a zbierka: NM-ČMH, inv. č. E 464

Dizajn a materiál: angulárny model s knihou, zahnutý súdok $\left(155^{\circ}\right)$, integrálne koleno $\left(117^{\circ}\right)$, krušpánové drevo, rohovinové prstence, diatonický basetový register

Klapky: 8 mosadzných klapiek štvorcového tvaru: $a^{1}, b^{1}$, as $/ e s^{2}, f / c^{2}, f i s / c i s^{2}, e / h^{1}$, basetová $d$, basetová $c$

Špecifiká: Nástroj je od roku 1997 zo zbierky odpísaný, spodné basetové klapky bez ochranných krytiek, spodný klapkový diel (stock) je integrálne prepojený s knihou.

Literatúra: LANGWILL 1972, s. 37; LANGWILL 1980, s. 41; YOUNG 1993, s. 65; GRASS, Thomas DEMUS, Dietrich: Das Bassetthorn. Seine Entwicklung und seine Musik, Books on Demand GmbH, Norderstedt 2002 (1. vydanie), s. 210; RICE 2009, s. 135.

6.

Basetový roh v F ladení, rok výroby 1793

kompletný 
Značka: Český lev / DOLEISCH / PRAG / 1793 / *

Lokalita a zbierka: NMM Vermillion, inv. č. 3541

Dizajn a materiál: angulárny model s knihou, zahnutý súdok $\left(155^{\circ}\right)$, integrálne koleno $\left(117^{\circ}\right)$, krušpánové drevo, rohovinové prstence, diatonický basetový register, vŕtanie 13,0 mm

Klapky: 8 mosadzných klapiek štvorcového tvaru: $a^{1}, b^{1}$, as $/ e s^{2}, f / c^{2}, f i s / c i s^{2}, e / h^{1}$, basetová $d$, basetová $c$

Špecifiká: Spodný klapkový diel (stock) je integrálne prepojený s knihou. Tá má zhora a zdola drevené krytky. Najspodnejšie klapky sú bez ochranných krytiek. Drevené prstence sú na hornom dieli zdobené.

Literatúra: HOEPRICH 2008, s. 241, obr. 10.4; RICE 2009, s. 135.

Dostupné online z http://collections.nmmusd.org/Exhibitions/Muzika/Muzikabassethorn.html [cit. 9. 4. 2021].

7.

\section{Basetový roh v F ladení, rok výroby 1796}

kompletný

Značka: Český lev / DOLEISCH / PRAG / 1796 / *

Lokalita a zbierka: NM-ČMH, inv. č. E 466

Dizajn a materiál: angulárny model s knihou, zahnutý súdok $\left(155^{\circ}\right)$, integrálne koleno $\left(117^{\circ}\right)$, krušpánové drevo, rohovinové prstence, čiastočne chromatický basetový register, vŕtanie 13,2-13,3 mm, celková dĺžka nástroja bez ozvučnice $980 \mathrm{~mm}$

Klapky: 9 mosadzných klapiek štvorcového tvaru: $a^{1}, b^{1}$, as $/ e s^{2}, f / c^{2}, f i s / c i s^{2}, e / h^{1}$, basetová es, basetová $d$ a $c$

Špecifiká: Spodné klapky $e / h$, basetové $e s, d, c$ majú ochranné krytky. Drevené prstence na hornom klapkovom dieli sú dekorované.

Literatúra: Průvodce, s. 33; LANGWILL 1972, s. 37; KELLER 1977, obrazová príloha (nečíslovaná piata fotografia); LANGWILL 1980, s. 41; KELLER, Jindřich: Sólo pro dva mistry (o hudebních nástrojich), Albatros, Praha 1982, s. 75; SHACKLETON 1987, s. 22, podč. pozn. 35; YOUNG 1993, s. 65; ČİŽEK, Bohuslav: Hudební nástroje evropské hudební kultury, Aventinum, Praha 2002, s. 130; BRECHLIČUKOVÁ 2003, 41, 43; GRASS-DEMUS 2004, s. 255; RICE 2009, s. 136; PIDDOCKE 2012, s. $94,147,174-175$.

\section{8.}

\section{Basetový roh v F ladení, rok výroby 1797}

chýba náustok

Značka: Český lev / DOLEISCH / PRAG / 1797 /**** / 3

Lokalita a zbierka: MIM, inv. č. MIM 938

Dizajn a materiál: angulárny model s knihou, zahnutý súdok $\left(155^{\circ}\right)$, integrálne koleno $\left(117^{\circ}\right)$, krušpánové drevo, rohovinové prstence, vŕtanie 13,8 mm

Klapky: 9 mosadzných klapiek plochého štvorcového tvaru: $a^{1}, b^{1}$, as $/ e s^{2}, f / c^{2}, f i s / c i s^{2}, e / h^{1}$, basetová es, basetová $d$ a $c$ 
Špecifiká: Všetky prstence sú dekorované. Kniha má zhora a zdola drevené krytky. Najspodnejšie klapky majú ochranné krytky. Pravdepodobne pochádza zo sady troch basetových rohov, v nej hral najspodnejší hlas.

Literatúra: GRASS-DEMUS 2004, s. 254; RICE 2009, s. 136.

Dostupné online z https://www.carmentis.be:443/eMP/eMuseumPlus?service=ExternalInterface\&module $=$ collection $\&$ objectId $=120885 \&$ viewType $=$ detailView $[$ cit. 9. 4. 2021] .

\section{9.}

\section{Basetový roh v F ladení, rok výroby 1798}

chýba ozvučnica

Značka na knihe: Český lev / DOLEISCH / PRAG / 1798 / ** (na dalších dieloch ***)

Lokalita a zbierka: PK, inv. č. M I/43

Dizajn a materiál: angulárny model s knihou, zahnutý súdok $\left(155^{\circ}\right)$, integrálne koleno $\left(117^{\circ}\right)$, krušpánové drevo, rohovinové prstence, čiastočne diatonický basetový register, vŕtanie 13,1-13,8 mm, celková dĺžka bez náustku a ozvučnice 895 mm

Klapky: 10 mosadzných klapiek štvorcového tvaru: 7 pôvodných: $a^{1}, b^{1}$, as/es ${ }^{2}, f / c^{2}, f i s / c i s^{2}$, $e / h^{1}$, basetová $c$, dodatočné klapky: $e s^{1} / b^{2}, c^{1} s^{1} / g i s^{2}, h^{1} / f^{2}$

Špecifiká: Nástroj má zdobené všetky prstence.

Literatúra: ČÍŽZKK 1981, s. 58; GRASS-DEMUS 2004, s. 263; RICE 2009, s. 136.

10.

\section{Basetový roh v F ladení, rok výroby 1798}

chýba náustok, súdok, horný klapkový diel, ozvučnica

Značka: 1 / Český lev / DOLEISCH / PRAG / 1798 / *

Lokalita a zbierka: PK, inv. č. M I/44

Dizajn a materiál: angulárny model s knihou, zahnutý súdok $\left(155^{\circ}\right)$, integrálne koleno $\left(117^{\circ}\right)$, krušpánové drevo, rohovinové prstence, čiastočne diatonický basetový register (iba $c$ klapka), vŕtanie 13,7 mm (stredný klapkový diel)

Klapky: 6 mosadzných klapiek plochého štvorcového tvaru, pôvodné klapky: as/es ${ }^{2}, f / c^{2}$, fis/cis ${ }^{2}, e / h^{1}$, basetová $c$, dodatočná klapka: $h^{1} / f^{2}$

Špecifiká: Nástroj má zdobené prstence. Torzo nástroja zahŕňa stredný a spodný klapkový diel a knihu.

Literatúra: ČÍŽEK 1981, s. 58; GRASS-DEMUS 2004, s. 263; RICE 2009, s. 157-158.

11.

\section{Basetový roh v F ladení, rok výroby 1798}

chýba náustok

Značka na knihe: 2 / Český lev / DOLEISCH / PRAG / 1798 / ****

Lokalita a zbierka: PK, inv. č. M I/42

Dizajn a materiál: angulárny model s knihou, zahnutý súdok $\left(155^{\circ}\right)$, integrálne koleno $\left(117^{\circ}\right)$, krušpánové drevo, rohovinové prstence, čiastočne chromatický basetový register, vŕtanie 13,8-14,4 mm, celková dĺžka bez náustku a ozvučnice 895 mm 
Klapky: 12 mosadzných klapiek plochého štvorcového tvaru: 9 pôvodných klapiek: $a^{1}, b^{l}$ (prefuková klapka), as/es ${ }^{2}, f / c^{2}, f i s / c i s^{2}, e / h^{l}$, basetová es, basetová $d$, basetová $c$, dodatočné klapky: $e s^{1} / b^{2}, c i s^{1} / g^{2} s^{2}, h^{1} / f^{2}$

Špecifiká: Nástroj má krytky na $e / h^{1}$ klapku a basetové $e s, d, c$ klapky. Prstence sú zdobené.

Literatúra: ČÍŽEK 1981, s. 58; GRASS-DEMUS 2004, s. 254; RICE 2009, s. 136.

12.

\section{Basetový roh v F ladení, rok výroby 1800}

kompletný

Značka: Dvojhlavý orol / DOLEISCH / PRAG / 1800 / *:**

Lokalita a zbierka: pôvodne súkromna zbierka dr. Charlesa Auranda v Tucsone v Arizone, dnes súčasté zbierky Michigan State University College of Music

Dizajn a materiál: angulárny model s knihou, zahnutý súdok $\left(155^{\circ}\right)$, integrálne koleno $\left(117^{\circ}\right)$, krušpánové drevo, rohovinové prstence, diatonický basetový register

Klapky: 13 mosadzných klapiek štvorcového tvaru, pôvodné klapky: $a, b^{1}, a s / e s^{2}, f / c^{2}, f i s / c i s^{2}$, $e / h^{l}$, basetová $d$, basetová $c$, dodatočné klapky:es $s^{l} / b^{2}, c i s^{l} / g i s^{2}, g i s^{l}, a / h$ trilková $h^{l} / f^{2}$ Špecifiká: Nástroj má zdobené prstence a ochranné krytky na najspodnejšie klapky. Literatúra: RICE 2009, s. 157-158.

Dostupné online z: https://www.music.msu.edu/news/something-old-something-new [cit. 9. 4. 2021]; Aurandova zbierka hudobných nástrojov, College of Music Michigan State University, zbierkový katalóg, s. 4 (posledná aktualizácia 1. 10. 2021), https://www.music.msu.edu/assets/Aurand_Collection_of_ Musical_Instruments_10-1-21.pdf [cit. 11. 10. 2021].

13.

\section{Basetový roh v F ladení, rok výroby 1803}

chýba náustok a ozvučnica, súdok nie je pôvodný

Značka: Dvojhlavý orol / DOLEISCH / PRAG / 1803 / *** / F

Lokalita a zbierka: RCM, inv. č. 90

Dizajn a materiál: model s knihou, zahnutý súdok $\left(155^{\circ}\right)$, integrálne koleno $\left(117^{\circ}\right)$, krušpánové drevo, rohovinové prstence, čiastočne chromatický basetový register, vŕtanie 13,2 mm Klapky: 9 mosadzných klapiek štvorcového tvaru: $a, b^{1}$, as $/ e s^{2}, f / c^{2}, f i s / c i s^{2}, e / h^{1}$, basetová es, basetová $d$, basetová $c$

Špecifiká: Klapky majú v drevených blokoch vsunuté kovové vodiace pivoty. Nástroj má zdobené drevené prstence na hornom klapkovom dieli. Basetové klapky majú páky narozdiel iných nástrojov rovnako dlhé. Páky klapiek fis/cis ${ }^{2}, e / h^{l}$ sú skrátené. Na knihe sú dve mosadzné oká na zavesenie nástroja pomocou šnúry pri hre v stoji: jedno na lavej strane knihy na zavesenie nástroja vpravo od hráčovho tela a druhé na spodnej strane knihy pre centrálnu pozíciu nástroja.

Literatúra: RICE 2009, s. 157-158.

Dostupné online z: http://museumcollections.rcm.ac.uk/collection/Details/collect/1227 [cit. 9.4. 2021]. 
14.

\section{Basetový roh v F ladení, rok výroby 1803}

chýba náustok, vrchný klapkový diel a ozvučnica

Značka: Dvojhlavý orol / DOLEISCH / PRAG / 1803 / ** / F

Lokalita a zbierka: MMP, inv. č. H 189 529/001

Dizajn a materiál: model s knihou, zahnutý súdok $\left(155^{\circ}\right)$, integrálne koleno $\left(117^{\circ}\right)$, krušpánové drevo, rohovinové prstence, diatonický basetový register

Klapky: 2 mosadzné klapky štvorcového tvaru: as $/ e s^{2}$ a $f / c^{2}$. Chýba klapka $f i s / c^{2} s^{2}$ a tiež dlhé ovládacie páky ku klapke $e / h^{l}$ a basetovým klapkám $d$ a $c$. V pôvodnom kompletnom stave mal nástroj aj klapky $a^{1}$ a $b^{l}$ na hornom klapkovom dieli a tým celkovo 6 klapiek.

Špecifiká: Na knihe sú dve mosadzné oká: jedno na lavej strane knihy na zavesenie nástroja vpravo od hráčovho tela a druhé na spodnej strane knihy pre centrálnu pozíciu nástroja. Dizajn klapiek as/es a $f / c^{2}$ nie je tak progresívny ako na Doleischovom basetovom rohu v zbierke RCM. Nástroj nemá zdobené drevené prstence. Chýba rohovinový prstenec na strednom klapkovom dieli.

Literatúra: YOUNG 1993, s. 65.

Adresa:

Róbert Šebesta, Vysoká škola múzických umení, Zochova 1, 81103 Bratislava, Slovenská republika E-mail: rsebesta@vsmu.sk

Daniela Kotašová, České muzeum hudby, Karmelitská 2, 11800 Praha 1, Česká republika E-mail:daniela.kotasova@nm.cz 